\title{
Determinants of Sustainability: an objective Indispensable for Micro Finance Institutions in Cameroon
}

\author{
R.T. Innocent Agha \\ Senior Lecturer of Human Resource Management, University of Douala, Cameroon
}

\begin{abstract}
By enabling the poor to have access to financial services, microfinance has proven to be a tool having a strong potential to reduce poverty. However, international development organizations and donors consider that, in order to contribute efficiently to poverty reduction, financial intermediation by microfinance organizations has to be sustainable. In other words, the more microfinance organizations will be sustainable, the better they will fulfill their social goal. The microfinance sector of Cameroon is characterised by a number of actors ranging from the category one through category two to category three microfinance institutions. As such, our main objective in this study was to describe how a micro finance institution builds its sustainability by identifying the various practices or means put in place. To achieve this objective, we employed the qualitative research approach through the case study strategy. Based on a number of criteria, three microfinance institutions were retained with each chosen from the various categories. An interview guide was designed to this effect involving five themes on which we collected information on the field using semi structured interviews with the selected microfinance institutions. The Information collected was analysed using content (thematic) analysis. Results obtained from this analysis reveal that the putting in place of human, organizational, technological, financial and cultural means or practices significantly enable microfinance institutions to be sustainable.
\end{abstract}

Keywords: Sustainability, Financial Sustainability, Microfinance, Microfinance Institutions.

\section{INTRODUCING THE CONTEXT OF WORK AND OBJECTIVES OF RESEARCH}

Microfinance is presented as one of the modes of financing development, palliating the insufficiencies of financing witnessed within the classical financial system of developing countries. Its importance increased in the field of the international policies of development, from the report of the harmful effects of the structural adjustment programs (SAP), imposed on developing countries following the world economic crisis of the 80s. For holders of multilateral institutions as the World Bank, as well as those of the neo - liberal ideology, microfinance presented itself as a means to integrate (include) the poor populations as actors of the global market, through a support to the micro enterprise of the informal sector by programs of microcredit, training of management and technical assistance. The micro- entrepreneur therefore saw himself attributed to virtues enabling him to incorporate himself in the growth process, as a means to reduce poverty (Peemans, 2002). The first microfinance programs that developed during the $80 \mathrm{~s}$ and $90 \mathrm{~s}$ were essentially of social vocation; they consisted in distributing credit on subsidization logic. The putting in place of these programs led to high rates of arrears, defaults and very high transaction costs.

This progressively let to the disappearance of many microcredit programs, thus it was difficult for the emergence of financial systems with perennial vocation (Adams, Graham and Von Pischke, 1984, Morduch, 2000), and poverty persisted in some zones despite a strong concentration of microfinance activities. In line with this, the beginning of the years 2000 generated the need of putting in place long lasting financial institutions, as decisive tools in the struggle against poverty. This resulted in the development of codes of' good practices' for the MFIs (Wampfler and Roesch, 2004). These good practices led to reflections on two axes; on one hand the question of impact and the other hand the diagnosis of the survival of these organizations (Labiate, 2001, p.19; Zeller, and Meyer 2002). It is on this last domain of reflection that our study shall be centered that oriented toward the sustainability of microfinance institutions in Cameroon. The importance of the sector of microfinance as tool to struggle against poverty increased during the last decade. Due to fallen socioeconomic conditions, the population turns more and more toward income generating activities. Microfinance activities developed for this purpose were, at the origin, quasi exclusively oriented toward a social mission and did not aspire at financial profitability. But the numerous bankruptcies that marked the MF sector 


\section{R.T. Innocent Agha}

caused an evolution of this original mission; from a sector of microfinance essentially centered on a social mission, toward a sector of microfinance activities striving to reconcile its social mission with an objective of financial viability. Surprisingly, the number of the active organizations in microfinance keeps on growing year in year out but, simultaneously, a great number of them are found leaving the market for one reason or the other, thereby dragging the loss of funds of customers and weakening the confidence bond between the public and the MF sector. This situation therefore becomes more and more preoccupying.

\section{Problem ANd ObJectives of The Study}

The growth of MFIs can be attributed to factors such as their contributions to social welfare, job creation and general economic improvement of lives of the poor. The primary objective of Microfinance institutions is enhancing outreach to the poor and by providing financial services on a sustainable base to alleviate poverty. However, the new hope brought by the rise of Microfinance institutions as a continuous source of finance to the poor and their MSMEs does not seem to last longer. Despite the interest in the sector as a poverty reduction strategy, it appears challenging to make an MFI viable (sustainable) over the long term. Surveys found that 30 percent of domestic microfinance programs operating in 2001 were either no longer in operation or were no longer lending capital two years later (Bhatt, Painter and Tang 2002). Furthermore, most microfinance programs report difficulty in sustaining their operations without continued reliance on grants, external fundraising, or other subsidies. In particular, there seems to be a major shift in emphasis from the social objective or mission of outreach towards the economic objective of sustainability and marketbased financial services (Rauf \& Mahrnood, 2009). Thus, the process prompts the assertion that if MFIs have to achieve their original goal of poverty alleviation, they have to be sustainable. This study therefore seeks to answer the question,

\section{How is The Sustainability OF A MiCRo FinanCE InSTITUTION CONSTRUCTED?}

More specifically, throughout this work we shall be striving to answer the following questions:

- Which are the practices frequently observed by micro finance institutions to be sustainable?

- What are the determinants of the sustainability of micro finance institutions in Cameroon?

As such, our main objective shall be to describe how a micro finance institution builds its sustainability and specifically,

- To bring out the practices frequently observed by micro finance institutions to be sustainable

- Identify the determinants of the sustainability of micro finance institution in Cameroon.

The focus on sustainability is attributed to the perspective that only independent, sustainable microfinance institutions will be able to attain the wide outreach necessary to achieve the highest level of impact on their target population, based on a globally affordable model that does not depend on long-term support, either from donors or the government (Robinson, 2003). To this effect, the main or principal proposition guiding the researcher is formulated as follows; the case study shall show how "Respect of minimum capital regulation of COBAC, growth of deposits, loan collection performance, System of governance, Human resources, physical and cultural proximity (outreach), personnel competence and the technology employed can contribute to build the sustainability of MFIs in Cameroon. On the other hand, the alternative (rival) proposition is formulated as; the case study seeks to show how "Respect of minimum capital regulation of COBAC, growth of deposits, loan collection performance, System of governance, Human resources, physical and cultural proximity, personnel competence and the technology employed are necessary but not sufficient to induce the construction of sustainability of MFIs in Cameroon".

\section{The QUESTION OF SUSTAINABILITY FOR A Micro FinANCE InSTITUTION}

\subsection{The Emergence and Evolution of Microfinance}

Poverty reduction was institutionalized in 1944, with the establishment of the World Bank at the birth of the Bretton Woods system. With the International Monetary Fund (IMF) assigned the tasks of stabilizing the world's economy and promoting free trade in the post WW II era, the problem of poverty was delegated to the World Bank. The industrial nations felt some responsibility for the world's poor; after all since Africa and parts of Asia, including India, had been colonies in European empires and they would need some help once they gained their independence. The strategy, with the U.S.A as leader, was to bring free trade to the developing world with the hope of integrating them into the formal economy. Since the World Bank's earliest days, attempts to reduce poverty have centered 
on large global organizations. Working through state governments and other formal institutions, credit was distributed to developing countries as long as they adhered to policies (programs) prescribed by the World Bank. These programs were called structural-adjustment programs (SAP), and they were highly unsuccessful. The focus of poverty reduction from the 1950s- 1980s was to integrate poor populations into the economy through better macroeconomic performance. Economists had identified the poor as part of a huge "informal" sector that remained "essentially invisible, in government plans and budgets, in economists' models, in bankers' portfolios, and in national policies" (Robinson, 2001). Until the 1980s the presence of informal microenterprises; street vendors, home workshops, market stalls, providers of informal transportation services was generally perceived by policymakers and economists to be a result of economic dys-functioning, Robinson (2001).

Microenterprises were thought of as little more than an indicator that the structure and growth rate of the formal economy were inadequate to absorb the national labor force, and so were perceived as à disguised form of unemployment. Microfinance supported these informal micro enterprises through microcredit. The microcredit approach to poverty reduction is "the provision of small loans to individuals, usually within groups, as capital investment to enable income generation through selfemployment" (Weber, 2006, pp.50). The poor's businesses were now seen as a symbol of unmet demand for credit. Poverty was now thought to be the result of market failure: A credit market failure occurs when a competitive market fails to bring about an efficient allocation of credit (Besley, 1994). Non-functional credit market is the main hurdle towards the end of global poverty as most of the time poor borrowers with good project to run might be credit constrained due to the exclusion by formal financial institutions (Fischer and Ghatak, 2011),

There are many reasons on the exclusion of poor households from formal banks; they include asymmetric information, moral hazards, adverse selection, high cost, and lack of tangible collateral. It is thus, difficult and costly to expand the financial inclusion as those agents who have inexpensive access to information and monitoring mechanism, to ensure reasonable repayments rate, may not have enough resources, and often face regulatory constraints, while those who have resources might face high information and monitoring charges makes it cost ineffective (Chaves and Gonzalez-Vega. 1996). Janvry and al. (2010) further argued that the reason behind the exclusion of poor from formal financial services are the problem of asymmetric information and cost inefficiency, and these problems are particularly severe in the poverty-focused credit markets where borrower lack collateral and credit histories. Stiglitz and Weiss (1981) describe asymmetric information as the most serious problem in less developed region, which leads to the credit rationing. In addition, without a good project to run, formal financial institutions do not lend for consumption purpose (Ledgerwood, 2001; Morduch, 2000; Hulme and Mosely, 1997). Thus, poor households in developing countries are highly dependent on informal loans from family, relatives, and friends. Tsai (2004) reports that about 40 percent of rural poor households in India depend on informal financial sources such as, relatives and friends, and further argues that it is not, however, a reasonable substitute for the formal financial institutions.

The interest rate on borrowing is also soaring high, however, the poor households in the rural area of developing countries have no other options than informal sectors to borrow loans (Morduch, 2005). Moreover, the most significant constraint that excludes rural poor households from borrowing by formal institutions is the lack of information about borrower behavior, which critically limits the ability of banks to guarantee repayment (Stiglitz and Weiss, 1981; Besley, 1994). Field research carried out by Mel and al. (2007) in Sri Lanka shows that the main constraint in expanding small business by poor entrepreneurs is the unavailability of finance as 78 percent of small business owners desire to expand their business, and 93 percent report lack of small loan is the main hurdle. Mel and al. (2007) also confirm that missing or nonfunctional credit markets are the significant problems to initiate and expand small entrepreneurship.

So far, more than 154 millions of poor people have been reached by 3552 Microfinance Institutions (MFIs) worldwide as of December 2007, where 69 percent were among the poorest and 83.4 percent were women (Harris 2002). Microfinance performs a conjuring-trick: it achieves higher rates of loan repayment than conventional banking, without having access to the collateral which conventional banks employ to protect their loan portfolio. It performs this trick through constructing social relationships, which substitute for collateral by putting pressure on the borrower to repay loans. These relationships may be either group-based (in which case pressure within the group peer is an important element in pressure to repay) or individual-based, in which case the pressure comes from loan officers 


\section{R.T. Innocent Agha}

and in some cases mentors and cithers within the client's community . Microfinance appeared as a fresh solution to an old problem. It appeared to be a "win-win" situation, where both financial institutions and poor clients profit. The "win-win" appearance of microfinance created unparalleled excitement in the world of economic development.

The today use of the expression microfinance has its roots in the 1970s when organizations, such as Grameen Bank of Bangladesh with the microfinance pioneer Mohammad Yunus, were started and shaped the modem industry of microfinance. Grameen Bank has been a source of ideas and models for the many institutions in the field of microcredit that have sprung up around the world. Savings and credit groups that have operated for centuries include the "susus" of Ghana, "chit funds" in India "tandas" in Mexico, "arisan in Indonesia, "cheetu" in Sri Lanka "tontines" in West Africa and "pasanaku" in Bolivia, as well as numerous savings clubs and burial societies found all over the world. Micro-credit has proved to be an important liberating force in societies where women in particular have to struggle against repressive social and economic conditions. It has helped to enable people excluded from the classical banking system to have access to financial services. The provision of financial services, especially credit and saving facilities plays an important role in the development of the economy.

\section{Conceptual Perspectives}

\subsection{The Concept of Microfinance}

There exist varieties of definitions to microfinance and the concept has become ambiguous as it has dispersed globally. One of the most frequently used and most recognized definition of microfinance is, however, the definition proposed by the Consultative Group to Assist the Poor (CGAP). They define microfinance as follows: Microfinance offers poor people access to basic financial services (CGAP, 2011). Broadly defined, microfinance includes both financial and social intermediation for low income men and women. Financial intermediation refers to the provision of a variety of financial products/services such as small savings and credit, insurance, pension and payment services. The social component relate to group formation, development of self-confidence, training in financial issues as well as the imparting of entrepreneurial skills. (Hermes and al. 2011, Rooyen and al. 2012) defined microfinance as any activity that includes the provision of financial and non-financial services such as microcredit, micro savings, micro insurance, training facilities, technical assistance, leasing, equity, money transfers to low income individuals who are excluded from the traditional banking system enabling micro-entrepreneurs and the poor to build businesses and improve their income, as well as the general economic wellbeing of the poor. Microfinance is considered providing financial services to low income groups and poor people, the original focus of micro finance was on the provision micro-credit (small loans) usually for short periods to finance working capital for small enterprises usually operate by low-income people, however the field of micro-finance has broaden greatly beyond credit only, to include micro-savings, micro insurance, remittances and other payments of which have a great impact on the lives of the poor (James, 2005).

The idea of microfinance is based on the concept that poor people's lack of access to financial services represents a serious obstacle for their economic development, management of daily life and getting resources to realize starting new businesses ideas or expand existing businesses and thereby struggle to for the poor are integrated into overall financial systems.

Robinson, 2003 refers Microfinance to all types of financial intermediation services (savings, credit funds transfer, insurance, pension, remittances, etc.) Provided to low income households and enterprises in both urban and rural areas, including employees in the public and private sectors and the self-employed. The definitions above differ in some senses but they all touch upon important features of microfinance. First, as CGAP's definition implies, microfinance means giving people access to financial services. It can be interpreted, just as BRAC states, that microfinance is aimed for those that do not have access to traditional financial services (Murdoch, 1999). Furthermore, the definitions by CGAP and BRAC pin-point that microfinance is aimed for poor people while Accion, on the other hand defines the target group as low-and-moderate income businesses or households. Robinson's as well as Acción's definitions do also, in contrast to CGAP' s definition, refer to services that are being addressed to income-generating businesses and even though many of the organizations that provide microfinance appeal to micro-businesses, there are microfinance programs that offer financial services to individuals as well. Grameen Bank in Bangladesh for example has a special microfinance program in which they are targeting beggars without any employment at all. Henceforth the term microfinance 
refers to financial services to those poor/ low-income households that have not got access to the traditional financial system.

\section{Sustainability OF MicrofinanCe}

The concept of sustainability is difficult to define, and its precise definition varies within differing contexts. The term sustainability is commonly used in many other fields such as environmental science, development economics, anti agricultural sector development particularly in the developing world where agriculture is the major economic sector or covers the vast share of the GDP of the countries. The concept of sustainability originates from natural science where it refers to the ability of a society ecosystem or any such ongoing system to continue functioning into the indefinite future without being forced into decline through exhaustion of its key resources (Robert, 1990). One oftenquoted definition of sustainability was provided in 1987 by the World Commission on Environment and Development: "as development that needs the needs of the present generation without compromising the ability of future generations to meet their own needs. More than two decades after the World Commission on Environment and Development defined sustainable development and put the concept of sustainability on the global agenda, the concrete meaning of the term and its suitability for specific cases remains disputed. However, regarding the development process, two primary aspects of sustainability emerge: economic and environmental sustainability. Both tie in with the notion of sustainable micro entrepreneurship; economic sustainability refers to a continual supply of finance to meet a person/community's needs, usually in the form of secure and accessible loans from a microfinance institution; and environmental sustainability is the aim to preserve environmental resources for use by future generations. Sustainable development (equating sustainability in microfinance parlance) suggests that an enterprise should not only integrate the economic dimension in its management, but should equally combine the social and environmental aspect (Etoundi, 2014).

In the context of microfinance, it is used interchangeably with self sufficiency, financial self sufficiency, profitability, financial sustainability, viability, financial efficiency, Ledgerwood, (1999); Johnson and Rogley, (1997); Huime and Mosley (1996); Christen and al., (1995); Yaron (1992). Effective, long-term provision of financial services occurs through microfinance institutions that adhere to the key principles endorsed by the Consultative Group to Assist the Poorest (CGAP) and its 28 member donors, which were further endorsed by the Group of Eight leaders at a Summit on June 10,2004 . The fourth key microfinance principle states that "Microfinance can pay for itself and must do so if it is to reach very large numbers of poor people. From bankers" perspective, a microfinance institution is said to have reached sustainability when the operating income from the loan is sufficient to cover all the operating costs (Sharma and Nepal, 1997). This definition adopts the bankers" perspective and sticks to "accounting approach" of sustainability as the "accounting approach" to sustainability that takes into account the financial aspect of the institution is too narrow. He states that the concept of sustainability includes, amongst other criteria obtaining funds at market rate and mobilization of local resources. Therefore, the performance assessment criteria for the financial viability of any microfinance related financial institution are: repayment rate, operating cost ratio, market interest rates, portfolio quality, and "demand driven" rural systems in which farmers themselves demand the loans for their project. From banker's perspective, sustainability of microfinance institution includes both financial viability and institutional sustainability (self sufficiency) of the bending institution (Sharma and Nepal, 1997). The terms of reference in the banker's definitions are therefore, more financial, administrative and institution focused.

\section{Dimensions of MiCrofinanCe SustainabiLity}

Sustainability in MF simply refers to the long term continuation of the Microfinance programme. It entails that appropriate systems and processes should be put in place that will enable the Microfinance services to be available on a continuous basis and the clients continue to benefit from these services in a routine manner. This also would mean that the programme would meet the needs of the members through resources raised on their own strength, either from among themselves or from external sources. Sustainability is defined as the capacity of a program to stay financially viable even if Subsidies and financial aids are cut off (Woolcock, 2006). Reaching the poor is major issue related to sustainability of MFIs. Reaching the poorest of the poor is more costly than reaching other segments of the market even when there are no fixed lending costs, and that leverage may be much harder to achieve for MFIs that target the "low-end" of the market. As such sustainability is a crucial factor for MFIs. The different dimensions of sustainability are: 


\subsection{Institutional or Organisational Sustainability}

With the growing number of micro finance institutions across countries, it is becoming increasing necessary for them to get structuralized. With structure comes an order and with order comes discipline and accountability, MFIs should, therefore, try to register under the right legal status because the pattern of ownership affects governance. Institutional sustainability looks at those dimensions of the organisation, which deals with the internal organisational environment (governance and accountability). These are the dimensions that make the organisation a wholesome, vibrant and a growing concern. Organizational sustainability has to do with the ability of the MFI to carry out tasks required to maintain outreach determined by the skills and knowledge of the bank's personnel, policies, systems and procedures.

According to Yaron (1997), institutional sustainability is necessary to attain a high level of financial sustainability and outreach. Institutional sustainability is possible where there is:

- A responsive organizational structure which encourages participation;

- A system and a procedure which are client focused, efficient flow of information, and sufficient transparency;

- A management team capable of translating the organization's objective into action;

- A system to secure appropriate human, financial and technical resources;

- A Motivated and skilled staff with the ability to efficiently execute and continuously refine and improve the operational methodology to better meet the organizational need.

\subsection{Mission Sustainability}

Sustainability of its mission is what will keep the organisation in its chosen path in the long term. Activities that the organisation is engaged in have to be constantly evaluated for its compatibility with the defined mission of the organisation. If changes are brought about in the mission, it would be through a well articulated and participatory process in the organisation.

\subsection{Programme Sustainability}

Programme sustainability occurs when stakeholders (clients) perceive that the services that they are receiving are of sufficient importance and value and are willing to assume responsibility and ownership for them. When this occurs the MFI can develop a phasing out strategy because the programme remains client supported and no externally subsidised support is sought.

\subsection{Human Resource Sustainability}

It means that the MFI is able to recruit, induct, train and maintain a well-qualified staff that is capable of delivering the services as required. Also the staff is able to monitor and maintain the organisation on the right track, keeping in mind the other parameters of sustainability.

\subsection{Financial Sustainability}

The first most important requirement for a micro finance institution is to be financially sustainable. Though sustainability does get understood immediately in financial terms, financial sustainability is only one major dimension of sustainability. Financial sustainability means that the MFI is able to cover all its present costs and the costs incurred in growth, if it expands operations. It would mean that the MFI is able to meet its operating costs, its financial costs adjusted for inflation and costs incurred in growth. Otero and Rhyne classifies financial sustainability into four levels, starting from the stage when the MFI is totally dependent on subsidies and grants for running its operations to the final stage when the programme is fully financed from resources mobilised from the clients and on funds raised from financial institutions on commercial rates of interest. Financial sustainability entails ability of the bank to continuously meet the financial requirements of its operations.

Financial sustainability is defined as the development of products and delivery systems that meet client needs, all prices that cover all costs of providing these financial services, independent of external subsidies (Rosengard, 200 1).Financial sustainability is expected to enhance the outreach of MFIs to poor people and thus stable and low-cost funds are crucial. It would mean that the MFI is able to meet its operating expenses, its financial costs adjusted for inflation and costs incurred in growth. Financial sustainability is a tangible parameter and can be measured and monitored continually through a set of indicator such as return on performing assets, financial cost ratio, loan loss provision ratio, operating cost ratio, donation and grants ratio, operating self sufficiency, financial self sufficiency (autonomy), etc. Financial sustainability and financial self-sufficiency are widely used 
concepts without any clear definition. According to León (2001) financial sustainability means ensuring the longevity of the organization. Financial Times' Lexicon (2011) states that selfsufficiency implies managing the operations without help from outside and Microfinance Information Exchange (MIX) provides yet another definition, stating that self-sufficiency refers to the organizations ability to fully cover its cost (MIX, 2011). Throughout this study, financial sustainability will refer to the ability for an MFI to survive in the long run by means of its own income generating activities, i.e. without any contributions from donors. The Sustainability ratio frequently used is that advanced by the MIX. The ratio is used as a measurement of the MFIs ability to continue to serve people in the future and is defined as: Operational self-sufficiency = Financial revenue/ (Financial expense + Impairment loss + Operating expense) (MIX, 201 1). This measurement examines how much of the total costs of the MFIs' programs that are covered by their financial income. Consequently a ratio of $100 \%$ means that the institution is able to fully cover its costs i.e. is self-sufficient (MIX, 2011).

\subsection{Market Sustainability}

This deals with the whole gamut of issues that deal with demand and supply of Microfinance. It deals with issues relating to the different types of the clientele, their differing types of needs, and designing products that suit the needs of this clientele. Servicing these needs in the most client friendly manner will lead to the sustainability of the demand. A sustainable supply of resources will need that the MFI is financially self- sufficient and meets all its costs from operations and has access to resources raised from the clients and from external sources at commercially viable rates of interest (Johnson and al., 2006). Market sustainability is also about availability of a large number of choices to the clientele. The MFIs sustain purely on the effectiveness and efficiency of its services and not due to artificially created imperfections (Rosenberg, 2003).

\subsection{Legal and Policy Environment Sustainability}

Market sustainability as described above assumes the existence of a stable and friendly legal and policy environment that will enable the proliferation of a large number of organizations involved in the delivery of Microfinance services. It would deal with issues relating to legal forms of organizations, interest rates, savings mobilization, and resource mobilisation from capital markets, from overseas commercial sources, etc.

\subsection{Impact Sustainability}

Microfinance has emerged as an effective methodology for alleviation of poverty among the disadvantaged sections. Thus, it is necessary that the services delivered by the different organisations have a positive impact on poverty. The positive changes that occur in the life of the poor family have to be sustained over the long term for the family to gradually emerge out of the state of poverty. Financial services play a critical role in reducing poverty. Permanent access to financial services can help poor people take control of their lives. When good practice is applied, financial services can put power into the hands of poor households, allowing them to progress from hand-to-mouth survival to planning for the future, acquiring physical and financial assets, and investing in better nutrition, improved living conditions, and children's health and education. Because financial services can be delivered sustainably, these benefits can be enjoyed well beyond the duration of donor or government programs. Through a participatory process involving multiple stakeholders, CGAP's members have defined a vision for the future of microfinance: A world in which poor people everywhere enjoy permanent access to a wide range of quality financial services, delivered by different types of institutions through a variety of convenient mechanisms.

Sustainability dilemmas in MFIs begin from strategic thinking arising from their consciousness of the changing operating environment. Looking at microfinance and MFIs on a broad sense, sustainability is a necessary condition for MFIs and the microfinance field as a whole to deliver their purpose for being (that is the ultimate purpose of these institutions is to ensure continued availability of credit for low-income borrowers). Donor funding and capital injection might be necessary at the start-up phase, but if a MFI is dependent on this and other subsidized loans continuously, the donors and benefactors can quickly run out of money (McIntosh and Wydick, 2005). To remain financially sustainable in an increasingly competitive environment, the idea to engage a profit-driven model creeps in.

Microfinance sustainability is a step towards profitability, they are both achieved when the institutions are able to reduce their transaction costs, offer better products and services that meet clients need, generate enough revenues and be able to find new financing ways to the unbaked poor households 


\section{R.T. Innocent Agha}

(CGAP, 2004). Microfinance sustainability starts with operational sustainability (OSS) were institutions cover the operating costs regardless the sources of revenue, it is then followed by financial self sufficiency (FSS) where the institutions cover operating revenue using operating revenues and unsubsidized capital base (Ayayi \& Sene, 2010; Forster et al., 2003). The last stage of sustainability is profitability where the institution is not only covering the operating costs but also the cost of funds, cost of inflation and all non cash costs entirely without subsidized funds (Barres et al., 2005, Makame \& Murinde, 2007; Rosenberg,2009; Christen, 1997; Morduch 1999). A profitable Microfinance institution generates excess funds which can be used for reinvestment and expansion of the institution. The growth and survival of these institutions depends on fund availability to cover for the operating costs as well as for the loans offered to the clients. Microfinance institutions which do not generate enough income from its operations depend on subsidies from donors to cover for operating costs and financing costs. The subsidies received by most institutions are not only very low compared to the demands but also their availability is uncertain (Rosenberg et al., 2009; Morduch, 2005).

\section{Theoretical Perspectives}

\subsection{Microfinance Poverty Reduction Approach Theories}

This section discusses two MFI approaches to poverty reduction. MF is considered as a tool for poverty reduction thus improved access to finance and financial services creates income generating capacity which may enable the poor to access all the development requirements to get out of multifaceted poverty and reduce their vulnerability to unexpected events. Thus the contribution of MF is seen through what is known as outreach (the capacity of a MFI to reach the poorer of the economically active poor).

\subsection{Emergence of the Need for Sustainability in MF}

The history of microfinance suggest that microfinance institutions did not start as business but rather as a means to alleviate poverty through helping the poor to create livelihoods for themselves (Harper, 2003). The microfinance services to the poor, therefore, were mainly offered by donor funded institutions. Between the 1970s and 1990, as microfinance evolved, the rooted doubt that the poor were not bankable was broken. Microfinance could reach millions of people (e.g. Grameen bank and Bank Rakyat Indonesia ((BRI). Moreover, it seemed as if the poor were able to save and repay the loan even at unsubsidized rates of interest (Harper, 2003). One question however, was still apparent, what is the appropriate approach to reach the poor financial system approach or poverty lending approach? While the financial system approach called for the need for microfinance institutions to sustain their operations without subsidy, the poverty lending approach was subsidy dependent, focusing on provision of cheap credit (Johnson, 2009: Robinson, 2001).

Some microfinance institutions like Bancosol in Boliva, BRI followed the financial system approach and continued to depend on subsidy to operate (Hulme, 2008). After the 1990, as more donors support became less reliable, most microfinance institutions started to think on how to sustain their operations without subsidy. This was only possible if they could earn more from their operations than their spending could require in absence of subsidy, Moreover, reaching the poorest within the framework of financial sustainability, as Johnson (2009) has put it, seemed impossible.

Following the perceived impossibility in reaching the poorest, around the year 2000 the consultative group to assist the poorest, which has taken a leading role in professionalizing microfinance, changed its name and its focus from the poorest to the poor. As a result of experience difficulties in reaching the poorest and becoming sustainable, most MFIs focusing on the poor, started thinking of being more market oriented to credit and savings to the poor (Rhyne, 2003). Likewise, around 2001 and 2002, the Grameen bank, which was seen as the main advocate and promoter of poverty lending approach, following financial difficulties that the bank faced, changed its structure from Grameen I to Grameen II.

While the original Grameen (Grameen I) followed by the poverty lending approach, the Grameen II approach takes it closer to financial system approach (Hulme, 2008). According to Harper (2003) the issue on how to attain sustainability has received a great deal of attention, ever since it was perceived impossible to reach the poorest. The need for sustainability in Microfinance institutions is a result of several factors from internal and external of Microfinance operations. Internally, the need for sustainability is a push from both employees and managers who require the going concern of the institutions to safe guide their employments especially when institutions receive no subsidies from donors (Morduch, 2000). Externally is first due to declining donor supports as a result of the 
increasing number of Microfinance institution requiring donor supports. Secondly, is due to changes in the operations and increased competitions as a result of increased involvement of commercial banks in microfinance services. Lastly, is due to changes in technology in the financial sector which facilitate efficient operations and decreased operating costs (Rhyne \& Otero, 2006; Hermes and al., 2011). Hence Sustainability of microfinance is hence becoming a more complex and debatable issue from different angles and is among the one of the important key principles of Consultative Group to Assist Poor (CGAP).

\subsection{Typology and Principles of Functioning of Mfis}

This typology of active organizations in microfinance is established on the basis of functioning principles. In general, the MFI could be classified according to two approaches and 7 models (Jacquier, 1999, pp. 60-70; Ndimanya, 2002, p.3-7). There are 2 competing views or approaches as far as poverty reduction is concerned; the institutionists (financial system approach) and the welfarist (poverty lending approach).These are also known as the major approaches used by MF1s as a tool to reduce poverty.

\subsection{Poverty Lending Approach}

Also known under the appellation of "controlled, Directed or Supply-Led Approach, this approach had characterized the first wave of the of microfinance programs, was based on the offer of inexpensive credit", "That is to say credit based on the subsidies of the state, organisms and donors. The welfarist emphasize on poverty lending measured by depth of outreach (reaching number of poor clients (Brau and Woller, 2004). The objective of the welfarists is to empower the poorer people of the economy achieve poor (depth of outreach). MFI should be in as far as possible, able to serve as many poor clients even when it might not appear profitable. The deficit in operation should be filled by donors, government support or social investors (Woller and al., 1999). The welfarist view that there is trade-off between sustainability (profitability) and targeting the poor (outreach) because the poor are cost ineffective to reach when sustainability is concerned thus donor support is required. Reaching the poor requires focused programs which cannot be sustainable and need on-going donor funding (Rhyne, 1998, Morduch, 1999).

The welfarists are based on the theory of social responsibility vis-à-vis the customer to meet its expectations (Carroll, 1979; Servet, 2007). This school of thought evaluates the performance of MFIs in terms of the customer through the social (outreach) and impact analysis (impact assessment): it targets the poor whose incomes are 50\% lower the poverty line (\$1 per day) and aims to improve their living conditions. It is composed mainly of supportive institutions, NGOs or cooperatives that see microfinance as a key means to reduce poverty of the poorest. Welfarists evaluate the sustainability of a MFI based on its contribution to the social welfare of the poor community. Their main focus is how MFIs could have social impact on its clients, the Poor. To them, MFI can attain sustainability without achieving self-sufficiency. To welfarists a sustainable MFI is one that is able of continuing its operations, reaching the poorest thereby contributing to poverty reduction regardless of whether this is achieved through subsidization. They support this argument by considering a subsidy to finance injected in a MFI in the form of equity invested by social investors who may not be there to make profits but to have a social impact (Brau and woller, 2004). To welfarists, MF sustainability is based on social merits rather than financial self-sufficiency (autonomy).

\subsection{Institutionalists or Financial System Approach}

Institutionalists on the other hand focus on financial sustainability of MFI. According to woller et al. (1999), institutionalists view financial deepening as the main objectives of MFIs. Financial deepening refers to creating sustainable financial intermediation for the poor. To institutionalists, financial deepening is measured by financial self-sufficiency (financial autonomy) and should be given a higher priority (Brau and Woller, 2004). This argument stems from the fact that in most cases, donor dependence is uncertain and unless a MFI is able to sustain itself financially, it will not be able to serve the poor on a durable base.

Contrary to promoting financial sustainability there is a potential tension that over emphasises on financial self sustainability may lead a MFI into moving away from its social mission (poverty reduction objective), Draye and Rhyne, 2002, stack and Thys, 2000. This is known as mission drift (Aubert et al., 2009, copestake, 2007). The institutionalists rely more on contract theory, which considers that incomplete contracts can lead to opportunistic behavior of applicants for credit (Guinanne Ghatak, 1999) institutionalists evaluate the performance of the institution in terms financial 


\section{R.T. Innocent Agha}

sustainability of MFIs . They designed a set of "best practices to increase the effectiveness of management systems (finance and accounting, marketing, service delivery, etc), whose adoption is an essential step to achieving financial self-sufficiency in industrial scale and access to financial markets. They consider financial independence as a criterion that best fulfills the social mission. Institutionalists view the sustainability of a MFI from the institution point of view. To them, the institutional sustainability of a MFI will be attained when the MFI is financially self-sufficient (autonomous), that is able to operate without subsidization. The emphasis here is that, for sustainability, a MFI should be able to cover its operating and financing costs with the program's revenue Brau Woller, 2004). A financially viable program is one where all costs (delivery and post delivery) of credit, provision for loan losses, inflation and return on investment are fully taken into account and covered by the interest rate charged on loans. With the institutionalists, a MFI should make profits to attract private capital because subsidies or donors may run out with time and consequently, the MFI may cease functioning (CGAP, 1995).

A close examination of the arguments put forward by the institutionalists and welfarists can reveal that it is a financing issue. On one hand institutionalists would like to see MFIs meeting their costs from self-generated funds with a possibility of making profits (without external funds). This is what they will call a sustainable MFI on the other hand; the welfarists are not concerned with where funds come from. To them, provided a MFI can continue with its operations and thereby meet their social objectives, they have attained sustainability,

Table1. Summary table of welfarists and institutionalists approaches to sustainable MF

\begin{tabular}{|c|c|c|}
\hline & Welfarists & Institutionalists \\
\hline Approach & $\begin{array}{l}\text { Performance evaluation from the } \\
\text { standpoint of customers: } \\
\text {-Social outreach } \\
\text {-Impact assessment }\end{array}$ & $\begin{array}{l}\text { Performance evaluation from the } \\
\text { standpoint of the institution: } \\
\text {-Broadness of the MFI } \\
\text {-Sustainability of the MFI. }\end{array}$ \\
\hline Targeted customers & Very poor $(\$ 1 /$ day $)$ & $\begin{array}{l}\text { Micro-entrepreneurs close to the } \\
\text { poverty line (\$2/day) }\end{array}$ \\
\hline Type of institutions & Social bonds & Commercial contracts \\
\hline Methodology & Resort to subsithes & Financial self-reliance \\
\hline Criticisms & $\begin{array}{l}- \text {-Sustainability } \\
\text { operation costs } \\
\text {-Various impact measurement } \\
\text { methods } \\
\text {-Failures (refunding rate }<50 \% \text { ) }\end{array}$ & $\begin{array}{l}\text {-Customers selection bias (MFIs do } \\
\text { not reach the very poor) } \\
\text {-High interest rates } \\
\text {-Long term self-reliance strategy }\end{array}$ \\
\hline Common goal & Poverty alleviation & \\
\hline
\end{tabular}

Source: Author's computation

The first part of this work enabled us to present the concepts of microfinance, sustainability and its different dimensions. It also enabled us to give an overview of MF in Cameroon the emergence of the need for sustainability in MFIs as well as the lending methodologies used by MFIs. We went further to present 2 opposing approaches in the MF industry worldwide and closely followed were empirical statutes that monitored the sustainability of MFIs. At present, we are at the realization phase of the study and we need to concretize it through the formulation of, a research methodoloy. This section brings out the methodological approach retained for this study, which is the qualitative approach with the case study as the research strategy.

\section{Methodology USED In THE REAllisation OF THE STUdY}

Methodology consists in the good usage of resources, methods and techniques (Aktouf, 1989). According to him, method is made up of a set of rules which in the framework of given science, are relatively independent in content and particular facts stated. It is translated on the field through concrete processes in the preparative organization and realization of a research work. Methodology brings out all the steps undertaken by the researcher to achieve the results presented. As a reminder, our research is aimed at showing how the MFI constructs its sustainability. To achieve this, a specific methodology is indispensable. That's why we are going to structure this chapter in 2 sections. The first will stress on the specific vision of sustainability in MFIs in Cameroon while the second section will bring out the methodology used to realize this study. In this chapter, the general objective is to present the notion of sustainability and also develop methods used to evaluate the sustainability of the three MFIs under survey. 


\section{SPECIFIC Vision OF Sustainability In MFis in CaMeroon}

\subsection{Presentation of MF Industry in Cameroon}

In this sub section, we shall present the industry in the Cameroonian context before proceeding to a deep description of the cases under study.

\subsection{The origin of MF in Cameroon}

The roots of formal MFIs in Cameroon can be traced far back as 1963 when the first credit union was set up at Njinikom in the North West region of Cameroon. Thanks to the work of a catholic reverend father who encouraged Christians to form groups as a way to help each other improve their economic situation by facilitating their access to Credit in the absence of Commercial Banks. This led to the first revolution of microfinance, which remained for a long time under the monopoly of the Anglophone regions of Cameroon before taking a national dimension. Today, with the current philosophy of little by little your savings grow, like the biblical mustard seed, it has grown to become the biggest network and player in the microfinance market of Cameroon under the umbrella institution Cameroon Cooperative Credit Union League (CAMCCUL). Apart from the CAMCCUL network, MFIs establishment in Cameroon setting aside CAMCCUL was discouraging until 1980s when the banking crisis led to the collapsed of series of commercial and developmental banks and subsequent closure of commercial banks branch network in most rural and semi urban areas, These expanded existing gap for the supply of financial and micro financial services in rural treas. From the year 1990, three principal factors have favored the birth and rapid expansion of this sector.

In the first place, the serious crisis of the 80s which severely affected the economy of the sub-region and in particular the financial system caused a profound restructurisation to be carried by states in all the sectors of the economy. In the domain of Banking, numerous bankruptcies were experienced within the CEMAC sub-region and this adversely affected many people, especially those of weak revenue. Moreover, most of these Banks did not offer credit in the pool; whereas access to credit is one of the most useful financial tool available to the POOL In this state of situation, a cross section of the population of these countries turned to other alternative sources such as tontines and Microfinance Establishments, which are fast becoming the locomotives of the economy.

In the second place, at the international level, the movement of microfinance intensified because it was henceforth considered as one of the essential tools for the fight against poverty. Finally, the activity of microfinance within the CEMAC States was performed in a "zig- zag" legal framework, for example in Cameroon the Law N ${ }^{\circ}$ 2/006 of 14 August 1992 relating to Cooperatives and Common Initiative Groups modified by Decree N'98/300/P.M of September 1998 fixing the modalities for the exercise of Saving and Credit Cooperative activities. These previewed only articles applicable to Saving and Credit Cooperatives, leaving aside the numerous structures who opted for a different legal form. Concerning the regulatory framework, regulation has been described as codification of public policy frame work (laws, institutions, and procedures) set for financial institutions to achieve a defined objective and/or act prudently with the ultimate objective of ensuring and sustaining financial system stability. Banks everywhere in the world are heavily regulated because of the strategic nature of their services to the economy.

Before 1998, microfinance institutions in Cameroon were supervised and placed under the control of the Ministry of Agriculture. During the period the activities of these institutions were seen as essentially suited for the promotion of rural and agricultural activities. However, as a result of many irregularities in the field and due to little or no supervision and control expertise at the level of personnel working in the Ministry of Agriculture, there was an urgent need to protect the public and guard depositors' funds. This resulted into a Prime Ministerial decree that puts the granting of licenses, supervision, and control of all MFIs under the Ministry of Finance and COBAC. In Cameroon, MFIs are regulated by three different laws: (1) the national law, (2) the Economic and Monetary Community of Central Africa (CEMAC) law instituted through COBAC, (3) the Pan African Organization for Harmonization of Business Law in Africa (OHADA). Each institution is compelled to comply with these frameworks paying attention to the basic prudential and nonprudential norms as stated by COBAC.

\subsection{Demand for Microfinance Services in Cameroon}

With a population of about 19.8 million and being the most populated country in the CEMAC zone, the microfinance industry of Cameroon continues to record an impressive growth in terms of members and account holders with current market intelligence estimate estimated at close to 


\section{R.T. Innocent Agha}

1,4million account holders. Thanks to vigorous reform programs launched to develop and enforce an adequate regulatory framework, measures put in place by the ministry of finance to protect depositors and strengthening internal control system put in place in some of these institutions in partnership with stipulated external auditors. According to current central bank statistics, 52\% of MFIs are located in urban areas as opposed to just $48 \%$ in rural areas. Today, within the network of microfinance institutions, cooperatives, and some common initiative groups carrying out savings and credits, it is estimated there are about 1.5 million accounts.

\subsection{Supply of Financial Services by Mfis in Cameroon}

In 2000, the banking Commission estimated the number of microfinance institutions operating in Cameroon at 652 and today, the number is estimated to be about 412 for both registered and unregistered MFIs. Majority of MFIs offer three principal services; they accept micro savings, grant micro credits, and carry out money transfers. Besides, other services such as micro insurance, mobile money, training and technical assistance to their customers are offered including a system for the settlement of bills (water and electricity bills) put at the disposal of the population. The master text prepared by COBAC for the regulation and control of MFIs focuses on the nature of activities of these institutions and not their legal form. This text classifies MFIs in three broad categories:

Category One: Are institutions that collect savings and deposits from members and lend them just to their members. This category includes associations, cooperatives and credit unions. There is no stipulated capital for category one institutions, instead COBAC text required the capital to be sufficient to cover and meet up with stipulated prudential norms.

Category Two: Are institutions that collect savings and deposits and lend them on to third parties. This category groups limited liability companies that function more like micro-banks. The minimum capital for category two institutions as stipulated by the text is FCFA 50millions. Proof of this amount must be shown in the form of a bank statement from any of the commercial banks.

Category Three: Is made of lending institutions that do not collect savings and deposits. They include micro credit and project financing institutions. The minimum capital requirement for a category three institution is FCFA 25millions. This amount must be fully paid with evidence shown in the form of a bank statement from a commercial bank as at the time of application for accreditation. On 30 November 2016, a total of 412 MFIs were authorized to operate in Cameroon in the year 2017, against 418 in 2016. These MFIs are classified into the three categories and also include those functioning in networks.

Category one institutions are the most represented on this list and are of a number of 121 .We have 42 in category two and 3 in category 3. The Cameroon Co-operative Credit Union League (CAMCCUL) is the largest network with 170 MFIs. The Union des caisses villageoises d'épargne et de crédit autogérés du Grand Nord (Uccgn) network has 9 MFIs, A3C has 34 MFIs, the caisses mutuelles d'épargne et de crédit ( $\mathrm{Cmec}$ ) has 9, 27 in the BINUM TONTINE network and lastly six in the mutuelles camerounaises d'épargne et de crédit (Mucadec) network.

Table2. Showing the distribution of MFIs according to categories and networks

\begin{tabular}{|c|c|}
\hline Category & Number of MFIs \\
\hline Category 1 & 121 \\
\hline Category 2 & 42 \\
\hline Category 3 & 3 \\
\hline Network & Number of MFIs \\
\hline CAMCCUL & 170 \\
\hline UCCGN & 9 \\
\hline A3C & 34 \\
\hline CMEC & 9 \\
\hline BINUM TONTINE & 27 \\
\hline MUCADEC & 6 \\
\hline
\end{tabular}

Source: Cameroon Tribune, Monday January 9, 2017 edition .page 21

\subsection{Presentation of Cases Understudy}

Before giving a detailed presentation of the cases understudy, we shall first of all give the criteria used to choose the cases; next we shall describe the cases, present the vision of sustainability for each of the cases interviewed and lastly present the difficulties uncounted. 


\subsection{Criteria of Choice for the Cases Chosen}

The choice of our cases under study was guided by several criteria amongst which are

Category: There are 3 categories of MFIs in Cameroon and because of the need for representative eness; we have chosen one MFI per category.

Size of the Enterprise: The size of the enterprises depends mostly on its turnover and the number of permanent staff. This has permitted us to select the MFIs retained for our study.

Sector of Activity: The sector of activity has greatly helped us to select the cases under study in the extent where. It has helped us to retain service industries of the secondary sector of an economy. It gives an estimate of $\mathrm{n}^{\circ}$ of MFIs in Cameroon with sources.

Branch of Activity: The branch of activity that guided the choice of our sample is the MF industry and has permitted us to concentrate on MFIs.

Date of Creation: Since sustainability is seen with time, the number of years in operation has guided us to select samples for our study. Our choice was based on MFIs having at least ten years of operation

\subsection{Description of Cases}

The cases above are those that have permitted us to identify sustainability practices in MFIs in Cameroon.

Table3. Presentation of cases

\begin{tabular}{|l|l|l|l|}
\hline CHARACTERISTICS & SOFINA & CCC & $\begin{array}{l}\text { SOLUTION FINANCES } \\
\text { GIE (SOFIN GIE) }\end{array}$ \\
\hline Sector of activity & Secondary & Secondary & Secondary \\
\hline $\begin{array}{l}\text { Main activity or } \\
\text { principal activity }\end{array}$ & $\begin{array}{l}\text { Provision of } \\
\text { financial services }\end{array}$ & $\begin{array}{l}\text { Provision of financial } \\
\text { services }\end{array}$ & $\begin{array}{l}\text { Provision of financial } \\
\text { services }\end{array}$ \\
\hline Branch of activity & MF industry & MF industry & MF industry \\
\hline Date of creation & 2001 & $07 / 11 / 1998$ & 2007 \\
\hline Type of enterprise & MFI & MFI & MFI \\
\hline Location & Akwa-754 rue Pau & $\begin{array}{l}\text { AKWA-Boulevard de la } \\
\text { liberté }\end{array}$ & $\begin{array}{l}\text { AKWA-Boulevard de la } \\
\text { liberté }\end{array}$ \\
\hline Categorization & $1^{\text {st }}$ category & $2^{\text {nd }}$ category & $3^{\text {rd }}$ category \\
\hline Social capital & 4.4 milliards XAF & 2 milliards XAF & 500 milliards XAF \\
\hline $\begin{array}{l}\text { Existence of } \\
\text { sustainability practices }\end{array}$ & Yes & Yes & Yes \\
\hline $\begin{array}{l}\text { Functions of people } \\
\text { interviewed }\end{array}$ & GM & AGM/HRM & DAF \\
\hline Juridical form & PLC & Plc & GIE \\
\hline
\end{tabular}

Source: author's computation

\subsection{Description of Cases Under Study}

As all these institutions are MFIs of the various categories duly registered according to the rules in place. They are all engaged in the provision of financial services to the public and have within them, the respect of a hierarchical structure starting from the board chairman through General Manager's to the least staff. This reflects the governance system within these MFIs and is a clear indication that they are all working towards being sustainable on the MF market in Cameroon. It is also noticed that these MFIs are privately owned mostly based on shareholder contribution. A brief presentation of each of the MFIs under study is given below based on the interviews the researcher had with each of the respondents.

\section{Sofina S.A (Societe Financiere Africaine)}

It is a category 1 MFI created in 1996 and has 16 branches in 4 regions of the country. Its headquarters is found in Douala. It has a customer base of more than 20,000 customers with about 80,000 accounts employing more than 250 permanent staff. Its main financial services are; savings, loans, money transfers, insurance services. Their motivation to survive on the MF market is based on the fact that, as a public enterprise, they manage public funds and are responsible with respect to the population. Our respondent in this case was the General Manager. 


\section{CCC Plc (Community CRedit Company)}

CCC PLC is a MFI of category 2 created on 07/11/1998. It is located in 6 regions of the country with the registered head quarter in Bamenda but operational headquarters in Douala. It has 18 branches (geographical coverage and outreach) with a customer base of more than 40,000 customers. Loans given out by this institution amount to about a billion FCFA and current customer deposit is approximately 12 billion. It has a permanent staff of 180 employees and offer salary payments, saving, loans, money transfers, bills and check discounting and contract financing as principal financial services. Our respondents during the interview were the Assistant General Manager and the Human Resource Manager;

- They handle money belonging to members of the public who have bestowed confidence in them. As such, they have a responsibility to ensure that these funds are saved by adopting sustainable practices.

- Another reason for struggling to survive in the MFI is that of the competence and commitment of their staff who want to secure their jobs thereby contributing to reduce unemployment in the country.

- Also, they are motivated to assist the Government in the poverty alleviation programme especially through support to the small and medium size enterprises.

\section{Solution FinanCES G1E (SoFin GiK)}

SOFIN GIE is a MM of category 3, created on 13/11/2007 under the registration number 1 839/MINFI. It is located at Akwa, Douala. It has a permanent staff of about 150 personnel and a customer base of more than 15,000 customers. It offers micro credit and project financing as main financial services. They are motivated to survive in the MF market firstly because they are out to assist those that need funds but cannot get access to these funds and secondly because workers want to secure their jobs. Our respondent in this case was the director of administrative and financial affairs.

\subsection{Vision of Sustainability in Each Case Interviewed}

Due to the fact that sustainability is a plural concept, each MFI proposed its own definition. According to the General Manager of SOFINA, sustainability is long-term survival, that is surviving at all moments, living and answering your responsibilities with respect to the various stakeholders involved (customers, shareholders, employees, the State, etc). He equated sustainability to durability, profitability and good governance. For the Assistant General Manager of CCC PLC, sustainability is the ability for a MFI to generate resources in order to cover costs incurred and at the same time is able to compensate investors (pay dividends). He went further to specify that sustainability is going beyond survival (having visions in the long run). To the human Resource Manager, survival is making ends meet but sustainability is the ability to continue to make ends meet in the long run. In both their ways of seeing, sustainability is a long term perspective while survival is short run.

According to director the administrative and financial affairs of SOFIN GIE, Survival is the process of devising strategies to make their products more competitive and attract and retain many customers. Sustainability is defined as the ability of the organization to meet the cost of the operations and build enough reserves for future investment opportunities. It involves making a profit margin to cover all charges incurred during operations and the ability to stay in the market for a long time. This definition is in accordance with the definition given by Okumu, (2007).

\subsection{Choice of the Research Methodology}

AKTOUF (1987) distinguishes different methodologies used in social sciences in general and management sciences in particular. All these are marked by epistemological approaches and range from rationalism, emperism, materialism, functionalism, interpretative to constructivism. Methodology in management sciences is marked by 2 epistemological approaches, which are: positivism and constructivism (phenomenology). In fact, there are many methods at the disposition of the researcher but the researcher has to choose, at one time, the method that he/she deems appropriate, given the nature, specificities arid exigencies of his object of study and his epistemological stand. The method retained for our study is the inductive qualitative method. 


\subsection{Presentation and Justification of the Inductive Qualitative Method}

Every research work should answer three fundamental questions: what? Why? and How? The question of what is aimed at identifying sustainability practices in MFIs in Cameroon. The 2 other questions are based on the research objet and the methodology chosen to achieve desired results. This choice is found at the center of the researchers' preoccupations because the answer to the main research question is found in the approach that the researcher will put in place to collect, analyze and present results.

This study seeks to show how a MFI becomes sustainable. To that, we need to understand, describe and explore a domain; that of sustainability of MFIs in the town of Douala and as such, we need to carry out an in-depth study into understanding the practices concerning sustainability in Cameroon MFIs. In addition, we need to know relationships and interrelationships between these practices in order to bring out those practices that will contribute to ameliorate the sustainability of MFIs. As such, the qualitative inductive method seems to be the most appropriate to answer our research question for it offers several advantages. Amongst these advantages are:

- The method statutes processes and permits the contextualization of a phenomenon. It has a great flexibility and enables adaptations to new and innovative theories

- It provides an in-depth description of the phenomenon under study and enables us to obtain information not likely to be obtained by other methods.

- It always puts the researcher at the center of the research exercise thus permitting him/her to acquire new experiences. Most importantly, the qualitative inductive approach puts the researcher in relation to the object of research thus creating a relationship of dependence between them.

- The qualitative approach involves a data collection process which requires limited numbers of respondents and a data collection process which can be carried out with limited resources.

- The key contribution of qualitative data is that it provides information about the human aspect of the emergency by acknowledging context to the priority needs of affected populations

- Finally, it leads to the construction of new theories by creating concepts from facts observed.

Table4. Operational framework

\begin{tabular}{|l|l|l|}
\hline Means put in place & Dimensions of sustainability & Indicators \\
\hline Financial means & Financial autonomy & $\begin{array}{l}- \text { Respect of minimum capital } \\
\text { regulation of COBAC }\end{array}$ \\
\hline $\begin{array}{l}\text { Organization and cultural } \\
\text { means }\end{array}$ & Institutional and social viability & $\begin{array}{l}\text { Loans recovery performance } \\
- \text { Phystem of governance } \\
\text { (Outreach) and cultural proximity } \\
- \text { Human resources available }\end{array}$ \\
\hline $\begin{array}{l}\text { Human and Technological } \\
\text { means }\end{array}$ & Technical efficiency & $\begin{array}{l}\text { Personnel competences } \\
- \text { Technology employed } \\
- \text { Information system }\end{array}$ \\
\hline
\end{tabular}

Source: Author's computation

\subsection{Sampling and Choice of the Cases Under Study}

Non probabilistic or (non-random sampling) provides a range of alternative techniques to select samples based on subjective judgment. To answer our research question and to reach our objectives, we need to undertake an in depth study that focuses on a small, perhaps one, case selected for a particular purpose. This sample will provide us with an information rich case study in which we shall explore our research question. Pires (1997) presents the non-probabilistic or empirical sample as the constitution of a sample resulting from a reasoned choice. This selection is done following some rules or criteria (as seen in section one). A number of non-probabilistic sampling techniques exist but the one retained for this study is the purposive sampling technique to select the cases in relation to our field of investigation (that is 3 MFIs). The purposive or judgmental sampling enables you to use your judgment to select cases that will best enable you to answer the research question and to meet your objectives. This type of sampling is often used when working with small samples as in a case study 


\section{R.T. Innocent Agha}

research and when you need to select cases that are particularly informative. As such, we have decided to apprehend and study the phenomenon of sustainability of MFIs in Cameroon through an in-depth case study by purposively basing our choice on 3 MFIs (SOFINA S.A, CCC PLC and SOFIN GIE).

\subsection{The Technique of Data Collection: Interviews}

By data, we mean a set of information, measures and gross observations that a researcher seeks to gather before passing it through all treatment, analysis and interpretations. This has as objective to provide answers to our main research question. Data collection process started with an extensive review of literature on sustainability and related concepts. Closely followed was the need for information to realize the study. This was made possible by carrying out interviews with some members of top management in the MFI under study. Because we are in the qualitative approach, it provides natural way of data collection rather than being artificial. The interview technique is used in our study. By interview, we mean an investigation process based on oriented discussion and using verbal communication. This enables us to acquire information that is in line with our objectives. An interview according to (Kahn, R and Carmel, 1957) is a purposeful discussion between two or more persons. Interviews can be highly formalized or structured using standardized questions for each respondent.

Our intention being to collect specific and original data from the part of each actor concerned, we proceeded with the use of semi structured interviews through the elaboration of a research protocol followed by an interview guide. Semi-structured interviews provide vital information on individual perspectives and experiences though direct discussion. Semi-structured interviews are nonstandardized. Here, the researcher has a set of themes and questions to be covered although they may vary from one respondent to another. Semi-structured interviews provide you with the opportunity to probe answers especially where you want the interviewees or respondents to explain or build on their responses and when you are concerned to understand meaning that respondents ascribe to a phenomenon. The interviews involve a set of key question which explore a phenomenon. The choice of the semi-structured interviews is based on the fact that it permits a face to face discussion with the respondents, to obtain information that is specific and offers a large range Or interpretation. Here, the person interviewed will have to answer directly to specific questions concerning the issue at hand (that of sustainability in MFIs in Cameroon). The role of the researcher here is to orientate or guide the respondents so that they will provide answers to the various themes that are in relation to our object of study. The researcher also needs to verify, through questions, particular points linked to the pre-established propositions.

\subsection{Analysis of Data Collected: Content Analysis of Themes}

Collecting data is one thing, but treating and analyzing it to solve a problem is another thing. To be useful, qualitative data needs to be analysed and the meanings understood. In the qualitative approach, like elsewhere, the researcher has to impose, on himself, a sense of rigor in order to satisfy criteria of being scientific. As such, the credibility of a researcher's work depends on his ability to generate analysis based on rigorous formalism that is coherent and non-superficial (Assoumou Menye, 1999).

Table6. Identification codes of respondents

\begin{tabular}{|c|c|c|c|}
\hline Respondents of enterprises & General Manager & $\begin{array}{ll}\text { Human } & \text { Resource } \\
\text { Manager } & \end{array}$ & $\begin{array}{l}\text { Financial and Adminis } \\
\text { trative Director }\end{array}$ \\
\hline SOFINA: IMF 1 & GM & - & - \\
\hline CCC: IMF 2 & AGM & HRM & - \\
\hline $\begin{array}{l}\text { SOLUTION FINANCES GIE: } \\
\text { IMF } 3\end{array}$ & - & - & DAF \\
\hline
\end{tabular}

Source: Author's computation

\subsection{Interpretation of Data}

Content analysis is based on the postulate that the repetition of elements during a discussion or series of discussions (words, expressions or similar meanings), reveals the center of interest and the meaning attached to it by actors. It is a good induction instrument to search for causes resulting from effects. After the exercises of transcription, categorization and coding, the interpretation of the data is realized. This enables us to define theoretical propositions by establishing an adequation between research questions and the analysis stemming from the exploitation of the collected and structured 
material in different themes. Interpretation of results shall lead to results as shall be presented in chapter 4.

Table7. Triangulation of data; methods of data collection and analysis

\begin{tabular}{|l|l|l|}
\hline Data sources & Methods of data collection & Methods of analysis \\
\hline $\begin{array}{l}\text { External data (articles; thesis; } \\
\text { documents) }\end{array}$ & Documentary review and interview & Contents analysis of themes \\
\hline Internal data & Semi structured interview & Analysis of themes \\
\hline
\end{tabular}

Source: Author's computation

After applying the methodology discussed in the previous sections, it is but obvious that the results be analysed and possible suggestions in the form of recommendations given to enrich the domain of research under study. We have collected a lot of information during our survey on the field, despite all the obstacles encountered. As such, we deem necessary to treat, analyse and interpret this data. For our study, we have opted for a transversal presentation of each theme to analyse the data collected from the selected MFIs retained for our study as shown in section I. This is closely followed by the results obtained (determinants of MF sustainability) in MFIs in Cameroon and possible recommendations in section 2 .

\section{Section 1: Sustainability of Mfis: Content Analysis of Data Collected}

Our major pre-occupation in this research work was to describe the process used to MFIs to build their sustainability and to finally determine those practices frequently observed to ensure this sustainability. To achieve this, we had to make sure that sustainability was important for those MFIs and those sustainable practices were implemented within these MFIs. Seen this way, our respondents were incited to present us their different sustainable practices and closely followed was the definition of key concepts in an operational way. The analysis of data resulting from field work within the selected MFIs is done following the themes spelled out in the interview guide. This section therefore consists of presenting the different means put in place by the MFIs to achieve sustainability so far.

\subsection{The Means Put in Place to Construct the Sustainability of MFIs}

\subsubsection{Human Means Put in Place}

In MFI, the management of their Human Resources is the core or heart of the success of their organization. By 2013, they had a staff of 220 employees but currently, they are having a permanent staff of 360 employees including both men and women (General Manager). Recruitment process is solely done based on competence and not on ethnic or religious considerations. After recruiting, they offer training courses to the new recruits and from time to time, internal training sessions like seminars and workshops stir up the working spirit in their personnel. Each employee is clearly sensitized on the mission of the company and the goals to be achieved. Additionally, good system of motivation is installed based on competence. Besides, the salary system is harmonized to ensure that employees with the same qualification and occupying the same functions have the same salary and advantages (General Manager). This eliminates discrimination and creates a sense of equity and belonging. As such, the staff is more motivated to work hence there's increased productivity and thus sustainability. Working conditions in MF1 are acceptable and constantly revised to fit the needs and exigencies of the personnel. There is also the putting in place of a bonus system to recognize well performing staff at the end of each year.

In MFI 2, the recruitment of personnel is based on competence and know-how. They avoid all sorts of racial, ethnic, religious and gender disparities. This is clearly seen by a mix all men, women, Anglophones and Francophone's within the organisation, asserted the AGM. They recruit and train new graduates before deployment to the various branches (HRM). From time to time, they offer refresher courses through internal and external training offered by both nationals and expatriates. This is to enhance the human capital of their personnel. Furthermore, a good motivation system is put in place for the personnel to feel at ease and be able to take care of their families as well. Remunerations here respect the national norms existing in the country and salary increases follow regulations in place and could be due to certificate, working experience (seen through number of years in duty) or age, etc. Salaries could also be revised following propositions by top management staff of the company. To crown it all, salaries are regular and they have installed the 13 months salary system or policy within the organization (AGM). Once recruited, a work contract is established and duly signed by the employee and the organization with terms well defined (AGM). 


\section{R.T. Innocent Agha}

Also, a clear job description is put in place on daily, weekly and monthly basis depending on the goal to meet. Each employee knows what to do and at what time thus this reduces wastage in time. A conducive work environment is put in place to enable the free sharing of knowledge and information between employees hence increasing their efficiency in operations. This is in accordance to Taiwo (2010). According to Opperman (2002), a work environment is made up of 3 components;

- The technical environment (tools, equipment, technology).

- The human environment (peers, other employees, team work, leadership and management) and

- The organizational environment (systems, procedures, practices, etc). This contributes to personnel efficiency. The AGM recognized that the productivity (efficiency anti effectiveness) of the personnel regardless of any type of business is the key to organizational success.

This is because workers who do not utilize their time and resources well are a burden (cost) on the organization. As such, much emphasis is laid on the work environment in MFI2 to ensure success hence permitting them to be sustainable. At the beginning, MFI 3 had 8 employees. But as time went on, they came to realize that a company needs an adequate labour force to perform its operations. As such, they adopted a policy of recruitment and training of personnel based on their savoir-faire and not discrimination. As put by the DAF, "we recruit and train personnel capable of adding a plus to us". This is seen through their staff number currently at about 150 employees. The Human Resources Department of MFI 3 organizes meetings to sensitize the personnel, problems are raised and solutions proposed for the advancement of the company. Once a new software is discovered or bought, the company organizes training sessions to get its personnel acquainted with it.

As put by the DAF, "workers are never satisfied with their salary levels and as such, salaries are frequently revised and more to that, we pay on fixed dates, usually the 2nd of each month". Besides, to make our staff feel secured at their job sites and to help them prevent unforeseen events (sickness, death, retirement), we have registered each of them to the National Social Insurance Fund (CNPS) and we also have a partnership with a hospital to take care of the health needs of the staff (FAD). As observed from the field human resources constitute the key component of these MFIs. This is seen through the recruitment and training of a good motivation system for their personnel before deployment to the various branches, comfortable work environment etc.

\subsubsection{Organizational Means Put in Place}

Within MFI 1, an operational scheme is devised in which targets per day; week, month and year are laid down. From here, the various tasks are assigned to the different personnel based on their knowhow. We ensure a maximum outreach by opening many branches with competent personnel to guarantee proximity to our customers. In MFI 2, an organigram is drawn as said by the AGM. This organigram is validated by the board. The organization or scheme chart of our organization ranges from shareholders, board of directors, managers, branches (agencies) (AGM). Within our organization as well spelled out by the HRM, "a General Assembly is held at least twice per year following the company law put in place". In this General Assembly, the general policy of the organization is defined for implementation by management through field managers and heads of divisions. There are also independent organs (external auditors and COBAC representatives that ensure that operations are done in conformity with the rules in place. To guarantee proximity to our customers, we ensure a maximum outreach by opening many branches with competent personnel at the service of clients.

MFI 3 is composed by a board of directors voted by members, committees (example supervision and staff committee) and management .There is a constant job description but from time to time, workers are permutated thus enabling them to acquire different skills. Within these MFIs, an operational scheme is devised in which targets per day; week, month and year are laid down, an organigram is drawn validated by the board ranging from shareholders, board of directors, managers, branches (agencies), a board of directors voted by members, committees (example supervision and staff committee) and management and there is a constant job description. This reflects the quality of the organization seen through their governance mechanism. Also these MFIs have adopted a strategy of maximum outreach by opening many branches thus guaranteeing proximity to their customers

\subsubsection{The Putting in Place of Technological Means}

As affirmed by the General Manager of MFI 1, "We buy softwares most adapted for our context". The software used is the same with those used by most classical commercial banks in their transactions. This enables us to provide quality services to our customers. They stress on the fact that a good 
quality system of technology will permit them to reduce transaction costs of operations in MFI 2. We use the most adequate software required for the circumstances, (HRM). In our case, we are using the "Delta Bank" software common with most commercial banks. This software is secured, performant and centralized. This software helps in decision making because it provides good, coherent and reliable forecasts and thus enables us to avoid some crisis in the future.

MFI 3 uses the ALPHA software suitable for our services and in addition to this we have good and reliable internet connection with support equipments like computers to help us satisfy or meet customers' expectations. As observed from our field work these MFIs buy softwares most adapted for their context. The softwares used are the same with those used by most classical or commercial banks in their transactions.

\subsubsection{Financial Means Put in Place}

This is one of the core elements to be considered when the sustainability of MFI is concerned as put by General Manager of MFI 1. He went further to assert that they have respected the minimum capital requirement stipulated by $\mathrm{COBAC}$. They also depend on shareholder contribution through shares and also on the growth of savings or deposits mobilized by customers. Besides respecting the minimum capital requirement, MFI 2 depends on shareholders contributions as explained to us by the General Manager. Furthermore, the HRM specified that in addition to shareholder contribution, they depend on customer deposits due to the confidence they have in their institution. Also, on commissions received on their placements in commercial banks and lastly on revenue derived from the services they offer to the public. All these constitute what the General Manager calls the budget defining both the sources of revenue and the charges to cover for a given period.

In MFI 3, they depend principally on shareholders contributions after having respected the minimum capital requirements and also on their partnership with their commercial bank. We can observe that the different financial means used by the METS are: the respect of the minimum capital requirement stipulated by COBAC, shareholder contribution through shares, deposits mobilized by customers, commissions received on placements in commercial banks, revenue derived from the services offered to the public and partnership with commercial bank. This enables them to cover the cost of their operations.

\subsubsection{The Putting in Place of Cultural Means}

In MFI 1, their manager emphasized that they have succeeded in developing a distinct culture known as the culture of "success together". They have a particular way of doing things. Employees feel free with each other because all reforms are based on equity. According to the General Manager of MFI 2, they have developed a culture of team spirit or community spirit. They have installed various activities to help employees socialize with each other. In MFI 3, they are based on solidarity between employees and the institution adopts the maximum presence strategy to encourage proximity. In MFI $1,2,3$; the various cultural means are success together, team spirit or community spirit, and solidarity respectively.

\subsubsection{Difficulties Observed in the Construction of the Sustainability of MFIs in Cameroon}

During our discussions with the respondents, they brought out the following as obstacles to achieving sustainability in MFIs in Cameroon. Despite all the efforts so far to satisfy the exigencies of the physical and cultural proximity through the creation of agencies, much still has to be done concerning the development of MF products and services that will satisfy the needs and expectations of their customers. SOFINA, CCC and SOFIN GIE have realized remarkable results so far in terms of responding to the financial needs of the population (for example; increase in savings, national outreach and volume of activities, micro-credit, customer fidelity, etc.). Notwithstanding that, its of a major interest to succeed in satisfying the financial needs of the population at large scale and to provide best quality services to their clients. But the development of adequate services is confronted to the question of profitability. For example, the AGM of CCC PLC during our discussion expressed that the vision of his organization is to develop products and services adapted to satisfying the needs of their clients but the institution is faced with the difficulty of identifying profitable services. It is worthwhile noting that the services and products offered are varied ranging from deposits (time deposits, savings, light deposits), to credits (for small businesses, housing, agriculture, etc) as well as the domiciliation of salary accounts, etc. But this diversification of services does not more or less 


\section{R.T. Innocent Agha}

result from a market development plan. That's why the GM of SOFINA S.A during our interview insisted on the pertinence of the comprehension of the management of the existing services before envisaging the introduction of new services and products.

Another major challenge faced by these MFIs is the absence of a development plan for their human resources. Much efforts have been tilted towards the recruitment and training of a qualified personnel capable of delivering quality services. This situation is not still solved and is even worsened by the relatively low salary levels existing within these MFIs. As noted by the HRM of CCC PLC, when they recruit and train workers, commercial banks offer them higher wages and they go away thus we have to spend more resources to recruit and train other personnel. This is clearly seen by the constant demand for salary increases in these institutions. Furthermore, another obstacle is the absence of a solid relationship with commercial banks and other actors of development. These 3 MFIs or the MF sector in general would have benefited from a strong relationship with classical banks. We can see that only MFI 3 affirmed having partnership with a commercial bank as a financial means. With their rapid expansion, these MFIs have been witnessing a high demand for credit which is directly linked to the level of savings mobilized. As such, if such level of savings is going to be a pressure on the demand for credit. Therefore, a serious collaboration between the MF sector, banks and other development actors will help the MF sector to have enough resources at their disposal to increase their lending capacity. Furthermore, acting together in synergy increases the efficiency of their operations and this will permit them to survive on the market.

These MFIs complained of lack of state support as a hindrance to their survival in the MF market: The sudden withdrawal of state support from the MF sector is a treat to the sustainability of the sector. State support is deficient in the sense that, there's no platform to support loan recovery by the government The AGM of MF2 went further to specify that such a support scheme exists in Senegal where conditions are put in place to take loan defaulters to court. Also, this sector faces heavy taxation from the State on its operations. This reduces their profitability and thus is a treat to their sustainability on the MF market. Also, the prevailing economic conjuncture in the country is also an obstacle to their expansion and thus sustainability as told by the GM of MFI 1. In addition, the AGM of MFI 2 pointed out both internal and external difficulties. Concerning internal obstacles, they are those directly linked to the organisation like deviant or undisciplined behaviors observed, constant salary increase demand by employees which if not met leads to resignation and problems during the recruitment and training of personnel.

Eternally, there's the confidence crisis provoked by the frequent closing down of MF'Is observed these recent years in the country. 'This has created panic in current and potential customers and has tarnished the image of MFIs in the country. As such these MFIs observe frequent non-repayment of loans.

\section{Section 2: Results Of The Means Put in Place and Managerial Contri BUTIONS FOR THE CONSTRUCTION OF THE SUSTAINABILITY OF MFIS IN CAMEROON}

In this section, our main concern is to present the results of the study. This will later on permit us to validate or refute our research proposition.

\subsection{Results of Means Put in Place to Build the Sustainability of MFIs in Cameroon}

\subsubsection{Human Results}

In MFI 2, the recruitment of personnel is based on competence and know-how. They avoid all sorts of racial, ethnic, religious and gender disparities. They recruit and train new graduates before deployment to the various branches (HRM). From time to time, they offer refresher courses through internal and external training offered by both nationals and expatriates. This is to enhance the human capital of their personnel. Furthermore, a good motivation system is put in place to personnel feel at ease and be able to take care of their families too. Remunerations here respect the national norms in relation to that salary increase following the regulations in place and could be due to certificate, working experience (seen through number of years in duty) or age, etc. Salaries could also be revised following based on propositions by top management staff of the company. To crown it all, salaries are regular and they have installed the 13 months salary system or policy within the organization (AGM). As such, much emphasis is laid on the work environment in MFI2 to ensure success hence permitting them to be sustainable. This has, as effect, to improve the customer and personnel confidence. Additionally, the personnel are more devoted to work thus increase productivity. The same effect is seen in MFI 1 and MFI 3. 


\subsubsection{Organizational Results}

Within MFI 1, an operational scheme is devised in which targets per day; week, month and year are laid down. In MFI 2, an organigram is drawn validated by the board ranging from shareholders, board of directors, managers, branches (agencies). MFI 3 is composed by a board of directors voted by members, committees (example supervision and staff committee) and management and there is a constant job description. This has as result a fast reaction to problems arising and proximity to customers is guaranteed.

\subsubsection{Technological Results}

As observed from our field work these MFIs buy softwares most adapted for their context. The softwares used are the same with those used by most classical or commercial banks in their transactions, for example MFI2 spoke of the DELTA software while MFI3 talked of the ALPHA software. These measures have as result the Efficiency of operations. This is in line with a study done by Ayayi and Sene (2010) which shows that significant reduction of operational expenses leads MFIs towards sustainability.

\subsubsection{Financial Results}

The respect of the minimum capital requirement stipulated by COBAC, shareholder contribution through shares and deposits mobilized by customers is used as the principal financial means in MFI1 has permitted them to obtain an improvement in net result which has improved their ability to cover costs thus making them financially autonomous. In addition to the above financial means, commissions received on placements in commercial banks and revenue derived from the services offered to the public are used by MFI2 and consequently, they have obtained increase in amount of deposits, efficiency of operations, growth in customer base, better loans collection performance and ability to cover costs as results. MFI3 which principally depends on shareholders contributions respected the minimum capital requirements and on partnership with their commercial bank has as result increase in customer base and confidence.

\subsubsection{Cultural Results}

By putting in place the various cultural means success together, team spirit or community spirit and solidarity in MFI 1, 2, 3 respectively has led to the Socialization of the worker in work place and easy insertion of the worker in the professional world. The above results provide basis to validate our main proposition and thus we can conclude that: the respect of minimum capital requirement of COBAC, growth of deposits, loan collection performance, System of governance, Human resource management, physical and cultural proximity (outreach), personnel competence and the technology employed significantly contribute to ameliorate the sustainability of MFIs in Cameroon. As such, the research concludes that, the putting in place of human, organizational, financial, technological and cultural means constitute the various practices frequently observed by MFIs in Cameroon to build their sustainability.

The analysis and interpretation of data has permitted us to present the results and at the same time we are capable of validating our research proposition. This result has made it possible for us to answer our research question and generate useful knowledge on practices that MFIs need to implement to construct their sustainability (human, organizational, technological, financial and cultural means).Based on the analysis and interpretation of the results from the 3 cases retained for our study, we noticed that they have some points in common; firstly, there's an increase in the customer base of the 3 MFIs since their creation(for example MFI 1 has customer base of more than 20,000 customers, MFI2 more than 40,000 customers, MFI3 has a customer base of more than 15,000 customers). Also the range of their activities has increased from the traditional services of micro credit and saving services to money transfers, micro insurance, salary payments, payment of bills, etc.

Secondly, in terms of their organizational structure, these MFIs are all constituted of a general assembly board of directors, general manager, branch managers, and heads of decisions till the staff. The implication of each of these members in the control and management of the MFI is favoured by its relatively small size. Furthermore, the use of information and communication tools is of great concern to these MFIs. Thanks to softwares exploited, the sharing of information between the agencies and the headquarters is possible. This enables a fast treatment of data and consequently, it facilitates decision taking. Information and communication technologies also enable us to share information between the different services, departments, etc of these MFIs. 


\section{R.T. Innocent Agha}

Again, they all strive to put in place a policy of recruitment based on competence and they ensure maximum outreach by opening branches throughout the country. The aim of bringing out the realisations or strong points of these MFIs is to show that these MFIs in particular and the MF sector of the country in general are on a good foot to ensure their sustainability.

\section{MANagerial Recommendations for the Construction of Sustainability by MFIS IN CAMEROON}

In this sub section, our main concern will be to give out some recommendations for the study following the results obtained above and later on present some of the limits of the study

\section{RECOMMENDATIONS OF THE STUDY}

Our study was based on 3 MFIs and from the analysis done, results have been presented though obstacles were encountered. It is therefore necessary that we bring out some points that still need to be exploited (recommendations) for these MFIs in particular and, for the whole MF sector of the country in general.

On the human resource plan, these MFIs need to invest more in their human resources in quantity as well as in quality. To better manage their growth and sustain themselves in the market, they need to invest in their human resources needed to provide quality services. To achieve this, it necessitates an important effort in the training and recycling of the personnel at all levels including managers. As such, the training of the personnel should not only be limited internally to sessions of organized punctual trainings but should be done through sessions, seminars or courses organized internally and externally. Personnel training should be based on important aspects like marketing, investment, the mastery of technology and banking techniques. These MFIs should equally be run by qualified managers. These managers can be granted study leave abroad to acquire extra managerial skills that will benefit their structures. On the other hand, a human resource policy will not have effect if much attention is not given to the remuneration of the personnel. As such, providing good work environment especially attractive and competitive salaries is indispensable for the recruitment and retention of competent personnel. However, this should be done without increasing operational charges.

In the technological domain, these institutions need to invest so as to acquire information and communication technologies adapted for their sector. With the growth of the MFIs through the creation of branches, investing in information system in the medium and long term especially sophisticated softwares, computers, Internet, etc is necessary. This can enable us to ameliorate financial results through cost reduction and increased productivity. Technology helps to better appreciate risk by limiting errors and enables communication between the branches and the headquarters. A competent personnel has to be trained on the use of these technologies to enable these tools fulfill their purpose.

Ameliorate their financial autonomy and palliating the increasing tension on the demand and supply of credit, more emphasis should be given to cooperation between MFIs, banks and other development actors. Since savings are necessary to favour auto-development, it is done by mobilizing external resources. As such, resorting to bank and donor refinancing is important through collaboration cooperation permit to ameliorate results through the fight against poverty thus achieving institutional and social viability. Collaboration between MFIs should also be encouraged. In this way, MFIs that have much liquidly can lend out their excess liquidity to those in need of liquidity. This constitutes the best way to mobilise financial resources needed to serve the poor which is their mission. Furthermore, for microfinance institutions to survive well in the market, the study recommends conformity to rules and regulations regarding registration and minimum capital requirements .Also, the government should elaborate more supportive programmes in favour of this sector which is seen as a poverty reduction strategy. Measures should be put in place to encourage savings since in literature and from the results of the study, the level of savings mobilized constituted a major source of finance used by these MFIs to carry out their operations.

MFIs are aimed to achieve the financial inclusion of those excluded from the classical banking system. This means they have to address the needs of the poor and low income earners. To achieve this, they have to identify new market segments and develop new products to suit their needs and 
exigencies. This necessitates the putting in place of specific programmes that will facilitate their access to the financial services that they need for their welfare. For example, group lending can be adopted to facilitate repayment and reduce default risks. In the meanwhile, care should be taken because offering financial services to the poor and low income earners is costly given that cost will be incurred in the training and sensitization of the programme through follow up and advice. The study recommends that microfinance institutions should open many branches so that they can be able to reach as many people as possible which will enhance their sustainability. The biggest sustainability factor for MFIs is to have a very broad client base. The poor in Cameroon constitute a very sizeable percentage of the population. MFIs should therefore, try to reach out the poor through easy, accessible and proper channels of service delivery.

\section{CONCluding Remarks}

The first part of this work has been concerned with the presentation of the context of the study which took us to the development of the research problem and objectives. Closely followed was the emergence and evolution of microfinance, the concept of microfinance and the concept of sustainability and its various dimensions in section one. In section two, we brought out the different stakes or importance of sustainability (economic, strategic and social) to an enterprise in general and to a MFI in particular. More emphasis on literature review was laid on the Emergence of the need for sustainability in MF, typology and principles of functioning of MFIs (in which we saw the welfarists and institutionalists approaches and lending methods used by MFIs worldwide) and lastly MF Development stages and sustainability. In section two, we focused on sustainability in debates looked at sustainability, profitability and outreach tradeoffs, empirical review that provided the factors that generally influence the sustainability of MFIs (like outreach, subsidy governance, age, etc).

Microfinance imposed itself in the field of international policies of development like a tool that can contribute to the reduction of poverty. From classical services of saving and credit the sector evolved with some organizations proposing a large range of services and products. A code of "best practices have been elaborated aimed to permit these institutions achieve sustainability. By basing on these best practices, we tried to assess the sustainability of three MFIs in Cameroon. The objective of this survey was to identify the various practices that would contribute to the sustainability of the actions of MFIs. The analysis revealed that the three institutions record a strong growth rate, in terms of number of members, of points of services, of volume of saving and credit. This growth constitutes an indispensable pillar, but it is not sufficient to assure the sustainability of an institution. To achieve sustainability, any institution must plan its growth so as to achieve a certain level of activities and maintain profitability, what constitutes a very difficult practice. From the practices or means identified in this survey, we were pushed to propose some strategic measures, for the three institutions in particular and for the sector in general, which would contribute to ameliorate the sustainability of the MFIs in particular and the MF sector in general. Faced with a microfinance sector in fast mutation, MFIs must adjust and innovate their current practices (Congo, 2003; CERISE, 1999). Innovation is vital and can apply to all domains: management, organization, products, institutionalization, etc. Congo proposes three types of innovations. The first, aiming to guarantee quality services are based on the conviction that it is only by maintaining quality services that we can solve the financial problems of the poor on a large scale thus achieving sustainability. In order to guarantee quality services, CERISE proposes an innovation based on the adaptation of the products to the customers, from a varied offer in order to better satisfy customer expectations and local economic specificities. The second type of innovation concerns institutional innovations. Structures must be adapted to the local potentials and to the needs of the targeted populations. The third type of innovation concerns financial innovations enabling MF systems to have additional lendable funds. These innovations insist on prioritizing the mobilization of savings, credit, and resorting to bank refinancing.

This study contributes to the literature in many ways. First, we extend the scanty and inconclusive empirical literature on the sustainability of MFIs by exploring a comprehensive set of sustainability practices and measures. In addition, since most of the previous studies have used quantitative methodology, this study has provided another way of apprehending the notion of sustainability in MF by making use of the qualitative approach. The micro finance system on the whole has been a successful endeavor in creating credit and saving opportunities for the poor and the low-income households. As a system, it has great potential and can go a long way in alleviating poverty in the country. There is therefore a need for MFIs to build a continuous lender-borrower relationship with 
their clients. As such, the regulatory environment guiding the micro finance system is of great concern. A good deal of work still remains in that front. Due to its increasing demand and utility, it is time that the government intervenes to provide the right regulations and directions to facilitate its functioning in Cameroon at large.

\section{REFERENCES}

[1] Acharya Y.P., and Acharya, U. 2006 "Sustainability of MFT from Small Farmer's Perspective: A case study of rural Nepal", Institutional Review of Business Research Papers, Vol. 2, N², pp. $117-126$

[2] Adongo, \& Stork, (2005), Factors Influencing the Financial Sustainability of Selected Microfinance Institutions in Namibia. Windhoek, Namibia: The Namibian Economic Policy Research Unit (NEPRU), Research Report

[3] AKtouf O. (1987), Méthodologie des sciences sociales et approche qualitative des organisations, une introduction à la démarche classique et une critique, les presses de l'Université du Québec, Montréal.

[4] Anita, C. (2012). Challenges to Microfinance Commercialization. Journal of Microfinance, $4(2), 57-62$

[5] Anne-Lucie and al. (2006), Overview of the Outreach and Financial Performance of Microfinance Institutions in Africa: Feature Articles Microbanking Bulletin, http://www.grieguitv.corn/resources/industry and issues/finance and microfinance/Africa_D

[6] Arun T. (2005), "Regulation for development: the case of microfinance". The quarterly review of Economies and Finance, 45, pp. 346-347.

[7] Barres I., Curran L., Nelson E., Bruett T., Escalona A., Noreil D., and al. (2005), Measuring Performance of Microfinance Institutions: A Framework for Reporting, Analysis and Monitoring. United States of America: The SEEP Network and Alternative Credit Technologies, LLC.

[8] Bernard G. A. (2012), Determinants of operational sustainability of micro finance institutions in Kenya. Retrieved from http://erepository.uonbi.ac.ke

[9] Besley T. (1995), Savings, Credit and Insurance In J. Behrman and T.N. Srinivasan, (eds.), Handbook of Development Economics, Volume 3A, Amsterdam: Elsevier Science

[10] Bhatt Nitin, Gary painter and shui -Yan Tang (2002), The challenges of outreach and sustainability In Replicating Microfinance in the united states : Carr. Eds .J. H.carr and Z. Y. Tong Washington, DC : Woodrow Wilson Center Press, pp. 19-221.

[11] Campion A. and Otero (1998), Current Governance Practices of Microfinance Institutions, Occasional Paper $\mathrm{N}^{\circ} 3$, The Microfinance Network, Washington, D. C.

[12] CERISE (1999), Les contraintes et les défis de la viabilité des systèmes de microfinance

[13] CGAP (2003), microfinance consensus guidelines: guiding principles on regulation and supervision of microfinance Consultative Group to Assist the Poor (CGAP), Washington. DC, June (2003).

[14] Christen R. P. and al. (1995), Maximizing the Outreach

[15] Christen R. (1997), Banking Services for the Poor: Managing for Financial Success:

[16] Christen R. (1997), Banking Services for the Pour: Managing for Financial Success:

[17] CIDA (1999) Reference Guide for Microfinance Sector. Canadian International Development Agency available at http://www.acdi-cida.gc.ca.çpendocument (Accessed: 20 December 2007).

[18] Congo Youssoufou (2003), Performance des institutions de microfinance en Afrique. Cas des caisses populaires au Burkina Faso, Thèse de doctorat en sciences économiques, Université de Liège.

[19] Crawford A., Skully M., \& Tripe, D. (2011), Are Profitable Microfinance Programs Less Efficient at Reaching the Poor? A Case Study in Cambodia. Retrieved 21, September, 2012, from http://ssrn.com!abstracÈl 968280 or http://dx.doi.org/19/ssrn. 1968280

[20] Daley-Harris S. (2002), Pathways out of Poverty. New York, NY: Kumarian Press. 
[21] Degefe D. (2007), Microfinance in Ethiopia: Elixir or poison? PhD diss Développement, Vol, 32, $\mathrm{n}^{\circ}$ 126, Editions De Boeck, Bruxelles- Paris.

[22] Diop A., Hillenkamp I. \& Servet J. M. (2007), Poverty versus inequality. In B. Balkenhol, Microfinance and Public Policy: Outreach, Performance, and Efficiency, pp. 27-46). New York: International Labor Organization and Palgrave Macmillian.

[23] DUCROUX, Christophe (2001), Les conditions de la pérennité des institutions de microfinance, Pôle microfinance, GRET (www.gret.org, consulté le 17 mai 2006).

[24] DUCROUX, Christophe (2003), "Combiner les services financiers et non financiers», BM, 15avril (httpp://wwwmip.org/pdfs/mhpIbundling_microfinunce_and_BDS .pdf, consulté le 10 mai 2006).

[25] Dyllick T. \& Hockerts K. (2002), Beyond the business case for corporate sustainability. Business Strategy and the Environment, 11(2), 130-141.

[26] Elkington J. (1998). Cannibals with forks: the triple bottom hue of $21^{\text {st }}$ century business. Gabriola Island: New Society Publishers en zones rurales défavorisées en Afrique, FENU.

[27] Etoundi E. G. C. (2014) ethique et developpement durable dans les PME Camerounaises, De Boeck Superieur /Monde en developpement, 2014 /4-n ${ }^{\circ}$ 168, 1sSN 0302-3052

[28] Fall F.S. (2011), La Complémentarité Banque/Microfinance dans les Economies en Développement: une Perspective Théorique, Revue d'Economie Industrielle, Vol. 133, N¹, pp. 31-56.

[29] Fall S. F., Onomo C. (2012), "La microfinance au Cameroun: Entre crise de gouvernance, crise de crédit et crise de régulation", Revue Techniques Financières et Développement, $\mathrm{N}^{\circ} 126$.

[30] Ganka D. (2010), "Financial sustainability of rural microfinance institutions in Tanzania", PhD thesis, University of Greenwich, Austrahia.

[31] GTZ et TRAM (2001), Viabilité sociale d'une IMF, Atelier de formation et de réflexion, Ouagadougou- Burkina Faso.

[32] GTZ et IRAM (2001), Viabilité sociale d'une IMF, Atelier de formation et de réflexion, Ouagadougou- Burkina Faso.

[33] Harris Sam (2002), Pathways Out of Poverty: Innovations in Microfinance for the Poorest Families, pp.264-5, 2002, Bloomfield, CT: Kumarian Presss

[34] Hartarska V. (2005), "Government and performance of microfinance institutions in Central and Eastern Europe", World

[35] Hartarska V. and Nadolnyak D. (2007), "Do regulated microfinance institutions achieve better sustainability and outreach? Cross-country evidence" Applied Economics, 29, pp. 1207-1222.

[36] Hermes N. and Lensink R. (2007), The Empirics of Microfinance: What Do We

[37] Hermes N., Lensink R.,. \& Meesters A. (2011), Outreach and efficiency of microfinance institutions. World Development, 39(6), pp. 938-948.

[38] Hermes N., Lensink R. and Meesters A. (2008), "Outreach and efficiency of microfinance Institutions”, [Onlinej Available: S’SRN: http://ssm.com/abstract (October 27, 2011).

[39] Ilishigsurem, G. (2004), "Evaluating mission drift in microfinance: Lessons for programs with social mission", Evaluation review, vol. 31, pp. 203-260.

[40] Hulme D. and Mosley, P. (1996), Finance against poverty, Routledge London.

[41] Isern J. and Porteous D. (2005), Commercial Banks and Microfinance: Evolving Models of Success, CGAP, Focus Note $\mathrm{N}^{\circ} 28$, June.

[42] Ismail, A. G., \& Mislan Condro, W. (2008), sustainability of BMT financing for developing micro- enterprises.

[43] Jacquier, Christian (1999), «L'épargne et le crédit solidaire dans les pays en développement », in Defourny, J., Develtere, P. et Fonteneau, B. (eds), L'économie sociale au Nord et au Sud, Editions De Boeck, Paris- Bruxelles, p.59-82.

[44] Jensen, M. and Meckling W. H. (1976), Theory of the Firm: Managerial Behavior, Agency Costs and Ownership Structure. The Journal ofFinancial Economies, 3, 305-360.

[45] Jonson S. and B. Rogaly (1997), Microfinance and Poverty Reduction: Oxfam Journal of Economics and Sociology 5 8(1) 
[46] Kabeer N. (2001), Conflicts over Credit: Re-Evaluating the Empowerment Potential of Loans to Women in Rural Bangladesh. World Development, 29(1), pp. 63-84

[47] Kaplan \& Norton (2004), Strategy Maps : converting intangible assets into tangible outcomes. Boston: Harvard Business School Press.

[48] Kaplan R. S., \& Norton D. P. (1996), The Balanced Scorecard: Transiating Strategy into Action. Boston, Massachusetts: Harvard Business School Press

[49] Kereta B. (2007), Outreach and Financial performance analysis of Microfmance Institutions in Ethiopia. Addis Ababa: African Economic Conference.

[50] Kyereboah A. (2007), "The impact of capital structure on the performance of microfinance Institutors", Journal of Risk Finance, vol. 8, pp. 56-7 1.

[51] Labiate M. (2001), "Corporate governance in microfinance organizations: A long and winding road", Management Decision, 39: 296-301.

[52] LABIE Marc (2004), «Microfinancement et développement », in Mondes en

[53] Leôn P (2001), Self four pillars of financial sustainability, Resources for Success Series, Volume2 retrieved July 11, 2011

[54] Lexicon (2011) Self-sufficient, retrieved July 11, 2011 from Financial Times Lexicon, link:http ://lexicon.ft.com/Term?terrnself_sufficient

[55] L000TRI (2006), "Building sustainable microfinance system: A growth of catalyst for the poor", Local govemment training and research institute, society for development stuthes, [Online] Available: http://www.logotri.net (September 10, 2011)..

[56] Makame A. and Morunde V. (2007), Empirical findings on Cognitive Dissonance around Microfinance Outreach and Sustainability. Birmingham: Unpublished paper, University of Birmingham. Available at: http://www.business. bham.ac.uk/events/papers/A_Makame.pdf (Accessed: 18 October 2012).

[57] Makombe I., Temba E., \& Kihombo A. (2005), Micro-Credit and Women "s Empowerment: Evidence from the Credit Scheme for Productive Activities of Women in Tanzania." In: Menon V. et al. (eds.) Alleviating Poverty: Case Stuthes of Local-Level Linkages and Processes in Developing World. India: Rainbow Publishers

[58] Markus O. (2009), Sedrecard use and Strategic Alignment in Non-Profit Organizations a case study of UNICEF Supply Division. University essay from Högskolan i Gavle/Institutionen för ekonom.

[59] McIntosh C. and Wydick B. (2005), Competition and Microfinance. Journal of evelopment Economics, 78, 27 1-298

[60] Mersiand, R. and Strom, R. (2009), "Performance and governance in microfinance institutions", Journal of Banking and of Microenterprise Finance: Analysis of Successful

[61] MIX (2011) About the data, Retrieved June 2011 from: Microfinance Information Exchange, link: http ://www.mixmarket.org/data-differences

[62] MIX (2011) Defining responsible financial performance: the role of profits, Retrieved July, 122011 from: Microbanking Bulletin, link: http://www.themix.org/puhlications/microhankingbulletin/20 11 /05/microfinance- profitsMlX (2011) Glossary, Retrieved July 12, $201 \mathrm{E}$ from: Microfinance Information Exchange, link: http://www.mixrnarke Lorg/enlglossary

[63] Morduch, J. (1999). The Role of Subsithes in Microfinance: Evidence from the Grameen Bank. Journal of Developinent Economics, 60, pp. 229-248.

[64] NDIMANYA Patrice (2002), La microfinance au Burundi ne remplit pas les conditions pour s'inscrire dans un cadre de développement durable, Faculté Universitaire des Sciences Agronomiques de Gembloux, Thèse annexe de doctorat en sciences agronomiques et ingénierie biologique.

[65] Nsabimana A. (2004). Articulation entre les Activités Bancaires et Microfinancières: une Nouvelle Sphère d'Intermédiation? Mondes en développement, Vol. 126, N², pp. 37-50.

[66] Olivares-Polanco F. (2005), Commercializing Microfinance and Deepening Outreach: Empirical Evidence from Latin America. Journal of Microfinance, 7, pp. 47-69 
[67] Paxton J., \& Fruman C. (1998), Outreach and Sustainability: A comparative analysis of Savingsfirst versus credit-first financial institutions. Sustainable banking with the poor. Washington, D.C., U.S.A.

[68] PEEMANS, Jean-Philippe (2002), «Le développement des peuples face à la modernisation du monde. Les théories du développement face aux histoires du développement "réel" dans la seconde moitié du XXème siècle», Collection Population et Développement, AcademiaBruylant/L' Harmattan, Louvain-La-Neuve/Paris.

[69] Peter C. (2007), "The Success of microfinance: What really sustains this poverty relief effort", free market forum discussion, School of Business, Nazarene University.

[70] Pierret D., Doligez F. (2005), "La gouvernance, noeud garthen de la microfinance ?", IRAM, Note thématique $\mathrm{N}^{\circ} 1$.

[71] Quayes 8. (2012), Depth of Outreach and Financial Sustainability of Microfinance Institutions. Applied Economics, 44, pp. 3421-3433.

[72] Rauf S. A., \& Mahrnood T. (2009), Growth and performance of microfinance in Pakistan.

[73] Raynard R., \& Forstarter M. (2002), Corporate social responsibility: implications for small and medium enterprises in developing countries. Retrieved June 10, 2007, from http://wn.unido.org/doc/5 162

[74] Rhyne E., \& Olero E. (2006), Microfinance through the Next Decade: Visioning the Who, What, Where, When and How. Global Microcredit Summit, Boston MA, ACCION International.

[75] Rosenberg R. (2009), Microfinance Institution Minimum Indicators that Donors and Investors Should Track. Washington DC: The World Bank.

[76] Rosengard J. K. (August, 2001), Kinks in the links: Financial intermediation for Africa's Poor. African Economic Policy Discussion Paper. 84. Boston: John F. Kennedy School of Government, Harvard University

[77] Sana T.A. (2004) "Microfinance regulation influence on small firms financing in Tanzania", Journal of financial regulation and compliance, 12(1), pp. 1358 - 1988.

[78] Schreiner M. (2001), Seven Aspects of Loan Size”. Journal of Microfinance, 3(2), pp. 27-48.

[79] Schreiner M. and Yaron J. (1999), « The Subsidy Dependence Index and Recent Attempts to Adjust it », in Savings and Development, 23(24), pp. 375- 405.

[80] Schriener M. (1997), Aframework for the performance and sustainability of subsithezed microfinance organnizations with application to Bancosol of Bolivia and Grameen Bank of Banglatheh. Ohaio: PHd dissertatio, Ohaio State Univ.

[81] Segrado C. (2005). The Involvement of Commercial Banks in Microfinance: The Egyptian Experience, Italy: MEDA Project.

[82] Sharma S. R. \& Nepal V. (1997), Strengthening of credit institutions/programs for rural poverty alleviation in Nepal: United Nations, Economic and (ECOSOC) for Asia and pacific, Bangkok, Thailand.

[83] Thapa G.B., Chalmers J., Taylor K.W. and Conroy J. (1992), Banking with the poor, report and recommendations based on case stuthes prepared by lending Asian Banks and non governmental organisations FDC, Brisbane, Australia.

[84] Thietart R. A. (2000), «Management et complexité: concepts et théories », centre de recherche DMSP cahier $n^{\circ} 282$.

[85] TriodosFact (2009), Wholesale Fund Good Practices: Findings Based on 17 Microfinance Wholesale Facility, Occasional Paper, the Netherlands

[86] Tucker M, Miles G. (2004), "Financial performance of microfinance institutions: A comparison to performance of regional commercial banks by geographic regions", Journal of Micro finance/ESR Review 6(1)

[87] UNESCAP (2006), Microfinance for Poverty Reduction: Building Inclusive Financial Sectors in Asia and the Pacific, Development Papers $\mathrm{N}^{\circ} 27$, Economic and Social Commissions for Asia and the Pacific, United Nations, Thailand. 
[88] Valenzuela L. (2002), Getting the Recipe Right: The Experience and Challenges of Commercial Bank Downscalers, in the Commercialization of Microfinance: Balancing Business and Development, edited by Drake D., Rhyne E. Bloomfield: Kumarian Press, pp. 46-74.

[89] Van Greuning H., Gallardo J. \& Randhawa B. (1998), A Framework for Regulating Microfinance Institutions, Financial Sector Development Department, World Bank

[90] Velasco C., \& Marconi R. (2004, March 30), Group dynamics, gender and microfinance in Bolivia. The Journal of International Development. Vol. 16, Issue 3, (pp. 5 19-528).

[91] Vinelli Andres (2002), "Financial sustainability is US organisations", in replicating microfinance in the United States. Eds. J. H. Carr and Z.Y. Tong. Washington DC Woodrow Wilson Center Press, PP. 137-165.

[92] WAMPFLER, Betty et ROESCH, Marc (2004), «Les ONG perdent-elles leur âme dans la microfinance? Eléments de réflexion à partir de l'étude de quinze ONG françaises », in GUERIN Isabelle \& SERVET Jean-Michel (eds), Exclusion et Liens financiers. Rapport du centre Walras, Edition Economica, Paris, pp.249-267.

[93] Weber H. (2006), The global political economy of microfinance and poverty reduction. In J. L. Fernando (Ed.), Microfinance: Perils and Prospects (pp. 43-63). New York: Routledge.

[94] Woller G., Dunford C. \& Warner W. (1999), Where to Microfinance, International Journal of Economic Development, 1, pp. 29-64

[95] Woller G. (2000), "Reassessing the financial viability of village banking: Past performance and future prospects", Micro Banking Bulletin, Microfinance Information Exchange (MIX).

[96] Woller G. and Schreiner M. (2002), "Poverty lending, financial self-sufficiency, and the six aspects of outreach", working paper, Washington, DC, USA.

[97] Woolcock (2006), " Learning from failures in microfinance What unsuccessful cases tell us how group based programs work “, American Journal of Micro finance, New York, pp. 16-26

[98] YIN R. K. (1994), Case Study Research: Design and methods (Applied Social Research Methods), ( $2^{\text {nd }}$ ed.)

[99] Zeller M. and Meyer R. L. (2002), "Improving the Performance of Microfinance: Financial Sustainability, Outreach and Impact" in Zeller M. and Meyer R. L. (eds), The Triangle of Microfinance: Financial Sustainability, Outreach and Impact, The Johns Hopkins University Press, Baltimore, pp. 1-14.

\section{AUTHOR's BIOGRAPHY}

R.T. Innocent Agha, has a $\mathrm{PhD}$ degree in International Marketing from the University of Calabar, Nigeria. He got his Master's and Bachelor's Degrees from the prestigious London School of Commerce. Dr. R.T. Innocent Agha is a certified International Human Resource Management Expert with several years of experience in Co-operative Management and Organizational Management. Innocent Agha is an Organizational Strategist in areas of, Organizational Development, Corporate Management, Marketing, Human Resource Management, Strategy Formulation To Change Management, Design And Delivery Of Management And Leadership Development Programmes. He has also been consulting for many Co-operative Management Institutions and Academic Institutions across the globe for international collaborations. Dr. R.T. Innocent Agha is a visiting lecturer at the Higher Technical Teacher Training College (HTTTC) Kumba, University Of Buea, ENSET, Bambili, University of Bamenda and University of Calabar. He is a permanent Senior Lecturer of Human Resource Management at the state University of Douala, Cameroon. Dr. R.T. Innocent Agha is a Researcher and Consultant of Co-operative Management. 